\title{
ENTRY, TRADE, AND EXPORTING OVER THE CYCLE
}

\author{
George A. Alessandria \\ Horag Choi \\ Working Paper 26212 \\ http://www.nber.org/papers/w26212 \\ NATIONAL BUREAU OF ECONOMIC RESEARCH \\ 1050 Massachusetts Avenue \\ Cambridge, MA 02138 \\ August 2019
}

This is a revised version of an earlier paper, "The Role Exporting and Trade for Entry over the Business Cycle." We have benefitted from conversations with Aubhik Khan and Satyajit Chatterjee and seminar participants at numerous conferences and universities. We thank Yoonsoon Lee and Ippei Fujiwara for helpful discussions. The views expressed herein are those of the authors and do not necessarily reflect the views of the National Bureau of Economic Research.

NBER working papers are circulated for discussion and comment purposes. They have not been peer-reviewed or been subject to the review by the NBER Board of Directors that accompanies official NBER publications.

(C) 2019 by George A. Alessandria and Horag Choi. All rights reserved. Short sections of text, not to exceed two paragraphs, may be quoted without explicit permission provided that full credit, including $\odot$ notice, is given to the source. 
Entry, Trade, and Exporting over the Cycle

George A. Alessandria and Horag Choi

NBER Working Paper No. 26212

August 2019

JEL No. E32,F41

\begin{abstract}
We study how international trade and the exporting decisions of establishments affect establishment creation over the business cycle in a general equilibrium model. The model captures two key features of establishment and exporter dynamics: i) new establishments start small and grow over time and ii) exporters tend to be bigger and more productive than nonexporters and remain so for some time. When the cost of creating establishments fluctuates with aggregate productivity, we find the model can generate procyclical fluctuations in the stock of domestic establishments and importers similar to the data. Without international trade, entry is weakly countercyclical and too smooth. The model also generates fluctuations in the stock of importers, exporters, and domestic establishments of similar magnitude to those in the data. With an entry margin, we also find that output is hump-shaped following a productivity shock since investments in creating establishments and exporters generate an incentive to delay accumulating physical capital. This hump is stronger in an open economy model and strongly increases the value of creating new establishments in a boom.
\end{abstract}

George A. Alessandria

Department of Economics

University of Rochester

Harkness 204

Rochester, NY 14627

and NBER

george.alessandria@ rochester.edu

Horag Choi

Department of Economics

Monash University

900 Dandenong Road

Caulfield East, VIC 3145

Australia

horag.choi@monash.edu 


\section{Introduction}

Recent research in international trade identifies an important theoretical link between the export decisions of establishments and the number of active establishments (Melitz, 2003). In this framework, reductions in marginal trade costs, such as tariffs and transportation costs, generate a large increase in the share of establishments exporting (Ruhl, 2003) and reduce the incentive to create new establishments (Baldwin and Forslid, 2010; and Alessandria and Choi, 2014a). For instance, Alessandria and Choi (2014) find an 8 percent reduction in tariffs increases export participation by 92 percent but reduces the stock of domestic establishments by two percent. While the effect of trade on entry is well understood, the effect of trade for the dynamics of entry over the business cycle is less understood. Indeed, much of the recent literature on establishment creation over the cycle, inspired by the large reduction in firm creation since the Great Recession, abstracts entirely from international trade. ${ }^{1}$ In this paper, we study the relationship between international trade and establishment creation over the business cycle in a general equilibrium model of endogenous entry into production and exporting.

We begin by documenting some salient features about the dynamics of the number of establishments, exporters, and importers over the business cycle. Our focus on more margins of market participation than in the closed economy literature permits a more nuanced view of the drivers of establishment creation and market participation. Moreover, as new producers tend to be much smaller than exporters, this sheds light on the different incentives of small and large producers to expand over the cycle. Consistent with previous research (see Chatterjee and Cooper, 2014; and Lee and Mukoyama, 2015), we find that both the number of new establishments and the stock of current establishments is procyclical in the U.S. We also find that when the number of domestic establishments is expanding so is the number of products being imported into the U.S. but even more strongly. In contrast, we find that the number of U.S. establishment exporting tends to be mildly countercyclical and negatively correlated with the stock of active domestic establishments. Finally, we find that fluctuations in the stock of establishments are about half as big as fluctuations in GDP, while fluctuations in the number of importers and exporters are about 1.5 times those of GDP, but half as volatile as trade flows. Thus, trade participation decisions are much more elastic

\footnotetext{
${ }^{1}$ See Pugsley and Sahin (2015), Clementi and Palazzo (2016) and Alon, Berger, Dent, and Pugsley (2017).
} 
over the cycle than the producer creation decisions.

To address the pattern of establishment creation and entry over the business cycle requires a model that captures key features of establishment-level heterogeneity. For our purposes, we extend the general equilibrium model of endogenous export participation of Alessandria and Choi (2007) to include an entry decision. In that model, which captures the key differences between exporters and non-exporters documented by Bernard and Jensen (1999), establishments differ in their productivity, capital stock, and export status. To become exporters, consistent with the model of Dixit (1989) and Baldwin and Krugman (1989) and the evidence in Das, Roberts and Tybout (2007), non-exporters incur a large, up-front sunk cost. To remain as exporters, establishments incur a smaller fixed cost. With heterogeneity in individual labor productivity and capital holdings, only the most productive non-exporters start exporting. Similarly, given the fixed cost of continuing in the export market, the least productive exporters exit the market. Over time, idiosyncratic productivity shocks lead establishments to enter and exit the export market. Thus, the model generates exporter hysteresis in that exporters continue to export even after they have become relatively unproductive or the aggregate conditions have changed in a way that they would not enter if they were not already in the market. We augment this model by allowing free entry so that new establishments are created with a one-period delay by incurring another sunk entry costs. With the structure of export cost in the model, new plants start small and grow through time as in the data.

To capture the cyclical features about entry, we consider two types of shocks: shocks to productivity and shocks to fixed costs of creating establishments and exporters. When the productivity of creating establishments and exporters moves with aggregate productivity, we find the model does well at matching a number of features about the cyclical fluctuations in the number of establishment. The model generates procyclical fluctuations in the number of establishments and importers and a positive correlation between domestic establishments and importers as in the data. The model also generates fluctuations in the number of exporters and importers that are about 1.5 times output and larger fluctuations in the stock of establishments. Holding the technology for exporting and creating establishments constant leads to much smaller fluctuations in exporters, importers, and domestic establishments.

Armed with a model that captures producer and exporter characteristics and dynamics and their evolution over the cycle, we consider some counterfactuals to show that international trade 
and the export decision of establishments play an important role in the dynamics of establishment creation. When we eliminate international borrowing and lending, the volatility in the stock of establishments falls by 44 percent relative to the benchmark model while fluctuations in participation by exporters and importers are cut by 65 percent. Eliminating the ability to borrow from abroad implies that when the home country receives a positive productivity shock, it will devote relatively more resources towards physical capital accumulation and less towards the creation of establishments or exporters. When we further eliminate intratemporal trade and the potential to export, the model now predicts acyclical fluctuations in the stock of establishments.

International trade in goods and financial assets helps to match the cyclical patterns of participation along these three margins because it generates fluctuations in output that are more persistent. The standard real business cycle model lacks a strong internal propagation mechanism from productivity shocks leading to output fluctuations that are mean reverting rather than humpshaped as in the data (Cogley and Nason, 1995). Others have shown that entry can help generate these hump-shaped dynamics if entry responds enough over the cycle (see Clementi and Palazzo, 2016). International trade in goods and assets further helps on this account for two reasons. First, it allows a country to borrow from abroad increasing the domestic capital stock faster and increasing future exports. A longer and larger boom increases the value of entry, pulling more new domestic producers and importers into the market. Importers soon retrench and exporters expand into foreign markets. Moreover, the greater investment is sustained because the interest rate does not rise by as much as in the closed economy which implies future profits from entry are discounted by less. Second, if entry costs are denominated in efficiency units of domestic labor then in a productivity driven expansion entry costs will fall relative to the price of capital which is a composite of imported and domestic goods leading to greater investment in new establishments.

Our analysis also sheds light on the nature of fixed trade costs. We find that abstracting from the export decision yields a stock of establishments that is much too procyclical. In this case as all producers engage in the foreign market without any fixed costs in exporting, there is greater incentive to create new establishments and export when there is a positive productivity shock. Thus the model predicts very strong procyclical fluctuations in the stock of establishment (0.92), and the stock of establishments becomes negatively related to importers (-0.08). Modelling exporting as a static decision makes entry strongly positively correlated with exporting and negatively correlated 
with importing, quite opposite from the data.

This paper is related to three lines of research. First, there is a closed economy literature that studies entry and exit of establishments over the business cycle. ${ }^{2}$ These papers abstract from plant heterogeneity. More recent work $^{3}$ consider aggregate fluctuations in models with heterogeneous establishments but abstract from international trade. Second, the international real business cycle model of Backus, Kehoe and Kydland (1994) has been extended to include exporting ${ }^{4}$ by Ghironi and Melitz (2005) and Alessandria and Choi (2007). Our approach differs from that in Ghironi and Melitz (2005), which also consider entry, in that we allow the underlying structure of establishment heterogeneity to differ and we allow for physical capital accumulation. We find including physical capital to be important for the propagation of shocks, since the durability of investments in establishments and exporters differ from that of physical capital. Moreover, physical capital is important to match the cyclicality of trade flows by creating a reason for productive economies to increase imports more strongly than exports in the early stages of a boom. Finally, there is a third, partial equilibrium literature that studies the export decisions of establishments. Baldwin (1988), Baldwin and Krugman (1989) and Dixit (1989) develop models of export decisions with an exogenous exchange rate process. ${ }^{5}$ Das, Roberts and Tybout (2007) develop these models further and use them to estimate the sunk costs of exporting. As partial equilibrium studies these papers cannot address the cyclical features of exporting or entry. Alessandria and Choi (2014a) and Alessandria, Choi and Ruhl (2014) extend these models to capture the lifecycle of producers and exporters, and study the transition from reductions in tariffs in general equilibrium. The sunk cost of exporting is important to capture the scale and timing of fluctuations in export participation since it becomes harder for this extensive margin to respond as sharply to aggregate conditions.

The paper is organized as follows. The next section discusses evidence on the dynamics of exporter participation and establishments over the business cycle. Section 3 develops a two-

\footnotetext{
${ }^{2}$ See Chatterjee and Cooper (2014); Devereux, Head and Lapham (1999); Cook (2001); Comin and Gertler (2006), Bilbiie, Ghironi and Melitz (2012).

${ }^{3}$ See Campbell (1998), Samaniego (2008), Veracierto (2008), Lee and Mukoyama (2015), Pugsley and Sahin (2015), Clementi, Khan, Palazzo and Thomas (2015), Clementi and Palozzo (2016) and Alon, Berger, Dent and Pugsley (2017).

${ }^{4}$ Cook (2002) and Head (2002) study entry in an international business cycle model but abstract from plant heterogeneity or the decision to export.

${ }^{5}$ Other papers that study the export decision include Roberts and Tybout (1997), Aw, Chung and Roberts (1998) and Clerides, Lach and Tybout (1998).
} 
country dynamic general equilibrium model with establishment and exporter dynamics. In section 4, we subject the model to country-specific shocks to productivity and examine the quantitative implications of the model for the exporter participation and establishment creation over the business cycle. Section 5 explores the sensitivity of the model to changes in the structure of trade, trade costs, fixed costs, the elasticity of substitutions, and the durability of investments in establishments. Section 6 concludes.

\section{Evidence}

We now discuss the long-run and cyclical movements in the number of establishments, ${ }^{6}$ importers, and exporters ${ }^{7}$ active in the U.S. from 1977 to 2015. Perhaps not surprisingly, given this is a period of substantial trade integration with the trade share of GDP nearly tripling, ${ }^{8}$ the number of producers active internationally (exporting and importing/foreign exporting) grows more than the number of active domestic establishments, particularly in manufacturing. Removing these long-run changes, over the cycle we find that the stocks of establishments and foreign exporters are strongly procyclical while exporting by US producers is largely acyclical, and international participation is more volatile than domestic participation. Consequently, we find the number of domestic producers and foreign exporters comove strongly while domestic producers do not comove much with exporters.

We focus on the number of active private establishments in the US economy and manufacturing from the Census's Business Dynamics Statistics. This is a measure of the stock of establishments active as of March 12 of a particular year. Their cyclical behavior has been studied in a number of recent papers (see for instance Tian, 2018; and Woo, 2015). Unlike this work which places a greater focus on the entry and exit margins we focus on the stock of establishments and bring in more information on trade participation.

Our measures of importers and exporters are based on counts of the number of goods imported and exported (see the data appendix for more details) over the course of a year. While these measures of changes in the number of goods imported or exported need not correspond to changes in the number of foreign establishments active in the U.S. market or U.S. establishments active

\footnotetext{
${ }^{6}$ For other studies of the cyclicality of producers, including entrants and exiters, see work by Koellinger and Thurik (2012), Woo (2015), Gourio, Messer and Siemer (2016), and Tian (2018).

${ }^{7}$ Ghironi and Melitz (2007) discuss fluctuations in these margins in the US from 1989 to 2001 using similar measures to ours. Alessandria and Choi (2007) study fluctuations in exporting to a panel of countries from 1996 to 2003.

${ }^{8}$ In 1977 the trade share of GDP in nominal terms was 10.7 percent while in 2015 it had risen to 29.1 percent.
} 
overseas, we do find that they are highly correlated with the participation by establishments, at least for U.S. exporters. ${ }^{9}$

Figure 1 plots the growth in establishments, exporters, importers, and private employment since 1977. Panel A shows that the stock of establishments has grown about as much as private employment while the number of products imported has grown nearly twice as much, consistent with growing trade integration. The number of products exported has grown slightly less than the number of private establishments but this primarily reflects a decline in exporters from 1977 to 1986, followed by a very robust expansion at about the same pace as importers. Panel b contrasts the dynamics of importers, and exporters against manufacturing establishments, perhaps a more natural measure given trade is primarily in manufactured goods. Here we see that the number of manufacturing establishments grew through the late 1990s before declining substantially. By 2015 there are about 15 percent fewer manufacturing establishments than in 1977 and a third fewer workers. ${ }^{10}$ By this measure there has been a robust expansion in exporters relative to domestic producers. ${ }^{11}$

Figure 2 plots the cyclical behavior of establishments, exporters, and importers and Table 1 reports some key business cycle statistics. ${ }^{12}$ Panel A plots the stock of establishments and real GDP. Importers and domestic establishments are procyclical (0.61 and 0.47) while exporting is essentially acyclical (-0.08). Establishments are more correlated with GDP than imports or exports (0.47 vs. 0.44 vs 0.31$).{ }^{13}$ Panel $\mathrm{B}$ and $\mathrm{C}$ show exporters and importers are half as volatile and strongly positively correlated with the appropriate trade flow ( 0.37 for exports and 0.70 for imports) suggesting there are many marginal exporters and importers. Panel D plots the ratio of nominal exports to imports along with the difference between exporters and importers and exporters and domestic firms.

\footnotetext{
${ }^{9}$ This measure of the number of goods exported is highly correlated (0.80) and of similar magnitude (percent standard deviation of 3.4 vs 4.6) as a measure based on the number of exporters from 1984 to 1992 in Bernard and Jensen (1999) and from the Exporter Database from 1996 to 2006. Based on this we conclude that our goods based measures are also likely to reflect participation decisions by establishments.

${ }^{10}$ Over this period manufacturing's labor share has declined so that the decline in employment overstates the decline in value added.

${ }^{11}$ In Alessandria and Choi (2014b) we document that export participation in manufacturing has grown nearly 40 log points among plants with 100+ employees and has nearly doubled among all plants from 1987 to 2007 in the US.

${ }^{12}$ The detailed description of data are reported in Appendix. All the data are $\mathrm{H}-\mathrm{P}$ filtered with the smoothing parameter of 6.25 after taking logarithm.

${ }^{13}$ We found that adjusting the timing of the measure of economic activity has a modest effect on the cyclicality of the stock of establishments. Using Q1 data on economic activity (since this lines up better with the March 12 measure of the stock establishments) rather than annual data makes the stock slightly more procyclical (+6 percentage points), more correlated with imports ( +12 percentage points) and less correlated with exports ( -5 percentage points).
} 
Here we see that net trade is strongly positively correlated with net export participation.

Relative to trade participation, the stock of establishments is about one-third less volatile, although of course trade is about 3 times as volatile as GDP. We also find that the stock of domestic establishments is less procyclical than importers (0.47 vs. 0.61$)$ but much more procyclical than exporters (0.47 vs. -0.08). The data thus suggests that participation margin of foreign suppliers is more responsive to U.S. booms than either the domestic participation or exporting margins.

Focusing on manufacturing plants yields somewhat similar results as the number of manufacturing plants has about the same volatility (50 vs. 45 percent) and procyclicality. ${ }^{14}$ The correlation between the stock of establishments and GDP is 0.47 , and the correlation between number of manufacturing plants and GDP is 0.41 .

We also find that when the stock of establishments rises, so does the stock of importers ${ }^{15}$ (correlation of 0.31 ), while the stock of exporters tends to fall (correlation is -0.28 for private establishments). The negative comovement between establishments and exporters is only possible if not all establishments export and the incentive to export varies relative to the incentive to enter.

The bottom panel reports the correlations between some variables at a one-year lag and lead. ${ }^{16}$ One thing that stands out is that GDP leads the stock of private establishments with a correlation of 0.57 between lagged GDP and current stock of establishment compared to a contemporaneous correlation of 0.47 . The gap is larger for manufacturing establishments: 0.79 vs. 0.41 . The correlation between establishments and lagged importers and exporters is a bit stronger now (0.57 vs. 0.31 for importers) and (-0.09 vs. -0.28 for exporters). When focusing on manufacturers, the correlation rises from -0.1 to 0.14 for exporter and 0.26 to 0.54 for importers. Our theory will explicitly allow for these types of timing issues in the measurement of active exporters and establishment.

\footnotetext{
${ }^{14}$ For manufacturers, the procyclicality with respect to value added in manufacturing is lower at 0.27 although it is more strongly correlated lagged manufacturing value added (0.81).

${ }^{15}$ We focus on the comovement between private establishments rather than manufacturing establishments since this will be consistent with the model we develop in the next section; however, we present statistics for manufacturing establishments for completeness.

${ }^{16}$ These dynamic correlations have been studied in Koellinger and Thurik (2012), Gourio, Messer and Siemer (2016), and Tian (2018).
} 


\section{The Model}

We now develop a model with infinitely lived consumers and heterogeneous establishments to study the role of trade and exporting on the entry decisions of establishments over the business cycle. The model combines elements of the Ghironi and Melitz (2005) framework of entry and exporting with the model of establishment exporter dynamics with capital of Alessandria and Choi (2007). Each period there is a mass of existing establishments distributed over productivity, countries, and export status. Establishment level productivity is stochastic and generates movements of establishments into and out of exporting. Each period, some establishments shutdown, and new establishments are created by incurring a sunk cost. Aggregate productivity fluctuates over time yielding aggregate fluctuations that influence entry and exporting decisions.

There are two countries, home and foreign. Each country is populated by a continuum of identical, infinitely lived consumers of mass one. Each period, the economy experiences an event $s_{t}$. Let $s^{t}=\left(s_{0}, s_{1}, \cdots, s_{t}\right)$ denote the history of events from period 0 up to and including period $t$. The probability of a history $s^{t}$, conditional on the information available at period 0 , is given as $\pi\left(s^{t} \mid s_{0}\right)$. The initial realization of an event at period $0, s_{0}$, is given.

In each country there is a large number of monopolistically competitive intermediate good producers each producing a distinct differentiated good. The many intermediate good producers are indexed $i \in\left[0, N\left(s^{t}\right)\right]$, where $N\left(s^{t}\right)$ is the mass of intermediate good producers in $s^{t} \cdot{ }^{17}$ An intermediate good producer uses capital and labor inputs to produce its variety. Producers differ in terms of total factor productivity, capital, location of production, and destination markets of sales. All establishments sell in their own country but only some establishments export. As in Dixit (1989), Baldwin and Krugman (1989), and Das, Roberts and Tybout (2007), to export, an establishment incurs a fixed cost that depends on its export status in the previous period. There is a (relatively) high up-front sunk cost $f_{0}\left(s^{t}\right)>0$ that must be borne to gain entry into the export market. In subsequent periods, to continue exporting, establishments incur a lower but nonzero period-by-period fixed continuation cost $f_{1}\left(s^{t}\right)<f_{0}\left(s^{t}\right)$. If an establishment does not pay this continuation cost, then it ceases to export. In future periods, the establishment can begin exporting only by incurring the entry cost $f_{0}\left(s^{t}\right)$ again. The cost of exporting implies that the set of goods

\footnotetext{
${ }^{17}$ To be precise, the index is reassigned each period based on shutdown producers and new producers so that all the establishments are indexed within the mass of producers.
} 
available to consumers differs across countries and is changing over time. We assume that the fixed costs must be incurred in the period of exporting. We consider alternative ways in which these costs may move in each country over the cycle.

In each period some establishments die and new ones are created. We follow Lee and Mukoyama (2008) and assume all establishments face a constant death probability $n_{d}$. New establishments can be created by incurring a sunk cost of $f_{E}\left(s^{t}\right)$. An entrant can actively produce goods and sell their products from the following period on. The timing of producer decisions is presented in Figure 3.

The cyclicality of entry costs will matter for the cyclicality and volatility of participation. In the literature, this is either explicitly assumed to be countercyclical (Bilbiie, Ghironi and Melitz, 2012) or implicitly by making the fixed costs denominated in final goods (Clementi and Palazzo, 2016). We follow the approach of making the entry costs explicitly countercyclical by letting productivity in a market affect the costs of entering that market. We prefer this approach to denominating entry costs in goods since international trade will be changing the composition of goods.

In each country, competitive final goods producers purchase intermediate inputs from those establishments actively selling in that country. ${ }^{18}$ The cost of exporting implies that the set of goods available to competitive final goods producers differs across countries. The entry and exit of exporting establishments implies that the set of intermediate goods available in a country is changing over time. The final goods are used for both domestic consumption and investment.

In this economy, there exists a complete set of one-period state-contingent nominal bond denominated in the home currency. Let $B\left(s^{t+1} \mid s^{t}\right)$ denote the home consumer's holding of the bonds purchased in state $s^{t}$ with payoff in state $s^{t+1}$. Let $B^{*}\left(s^{t+1} \mid s^{t}\right)$ denotes the foreign consumer's holding of this bond. The state-contingent bond $B\left(s^{t}\right)$ pays 1 unit of home currency if $s^{t}$ occurs, and 0 otherwise. Let $Q\left(s^{t+1} \mid s^{t}\right)$ denote the nominal price of the bond $B\left(s^{t+1}\right)$. All the intermediate and final good producers are owned by domestic consumers. It is assumed that these ownership claims cannot be traded.

\footnotetext{
${ }^{18}$ There is no value added in this stage of production. The final good production technology regulates a country's preferences over local and imported varieties.
} 


\section{Consumers}

Home consumers choose consumption, labor, and bond holdings to maximize their utility:

(1) $\max \sum_{t=0}^{\infty} \int_{s^{t}} \beta^{t} \pi\left(s^{t} \mid s_{0}\right) U\left[C\left(s^{t}\right), L\left(s^{t}\right)\right] d s^{t}$,

subject to the sequence of budget constraints,

$$
P\left(s^{t}\right) C\left(s^{t}\right)+\int_{s^{t+1}} Q\left(s^{t+1} \mid s^{t}\right) B\left(s^{t+1}\right) d s^{t+1} \leq P\left(s^{t}\right) W\left(s^{t}\right) L\left(s^{t}\right)+B\left(s^{t}\right)+P\left(s^{t}\right) \Pi\left(s^{t}\right),
$$

where $\beta$ is the subjective time discount factor with $0<\beta<1 ; P\left(s^{t}\right)$ is the price of the final good; $C\left(s^{t}\right)$ is the consumption of final goods; $W\left(s^{t}\right)$ is the real wage rate; and $\Pi\left(s^{t}\right)$ is the sum of real profits from the home country producers. The instantaneous utility function is given as

$U(C, L)=\left[C^{\gamma}(1-L)^{1-\gamma}\right]^{1-\sigma} /(1-\sigma)$, where $1 / \sigma$ is the intertemporal elasticity of substitution, and $\gamma$ is the share parameter for consumption in the composite commodity.

The problem of foreign consumers is analogous to this problem. Prices and allocations in the foreign country are represented with an asterisk. Money has no role in this economy and is only a unit of account. The foreign budget constraint is expressed as

$$
\begin{aligned}
P^{*}\left(s^{t}\right) C^{*}\left(s^{t}\right)+\int_{s^{t+1}} \frac{Q\left(s^{t+1} \mid s^{t}\right)}{e\left(s^{t}\right)} B^{*}\left(s^{t}\right) d s^{t+1} \leq & P^{*}\left(s^{t}\right) W^{*}\left(s^{t}\right) L^{*}\left(s^{t}\right) \\
& +\frac{B^{*}\left(s^{t}\right)}{e\left(s^{t}\right)}+P^{*}\left(s^{t}\right) \Pi^{*}\left(s^{t}\right),
\end{aligned}
$$

where ${ }^{*}$ denotes the foreign variables and $e\left(s^{t}\right)$ is the nominal exchange rate with home currency as numeraire. ${ }^{19}$

\section{Final Good Producers}

In the home country, final goods are produced using home and foreign intermediate goods. A final good producer can purchase from any of the home intermediate good producers but can purchase only from those foreign intermediate good producers actively selling in the home market. The set of foreign intermediate good producers actively selling in the home country is denoted by

\footnotetext{
${ }^{19} \mathrm{An}$ increase in $e\left(s^{t}\right)$ means a depreciation of domestic currency.
} 
$X^{*}\left(s^{t}\right)$, where $i \in X^{*}\left(s^{t}\right)$ if the $i_{\text {th }}$ producer is a foreign exporter in $s^{t}$.

The production technology of a final good producer is given by a constant elasticity of substitution (CES) function

$$
D\left(s^{t}\right)=\left\{\lambda\left[\int_{0}^{N\left(s^{t}\right)} y_{h}^{d}\left(i, s^{t}\right)^{\theta} d i\right]^{\frac{\rho}{\theta}}+(1-\lambda)\left[\int_{i \in X^{*}\left(s^{t}\right)} y_{f}^{d}\left(i, s^{t}\right)^{\theta} d i\right]^{\frac{\rho}{\theta}}\right\}^{\frac{1}{\rho}}
$$

where $D\left(s^{t}\right)$ is the output of final goods and $y_{h}^{d}\left(i, s^{t}\right)$ and $y_{f}^{d}\left(i, s^{t}\right)$ are inputs of intermediate goods purchased from home establishment $i$ and foreign establishment $i$, respectively. The parameter $\lambda$ determines the weight of home goods in final good consumption. The elasticity of substitution between intermediate goods that are produced in the same country is $1 /(1-\theta)$, and the elasticity of substitution between home and foreign aggregate inputs is $1 /(1-\rho)$. With the two entry margins of the model, the measure of varieties available for use in production of the composite home and foreign good changes over time. With a typical Dixit-Stiglitz aggregator there is a benefit to using smaller amounts of a greater number of varieties.

The final goods market is perfectly competitive. In each period $t$, given the final good price at home $P\left(s^{t}\right)$, the $i_{\text {th }}$ home intermediate good price at home $P_{h}\left(i, s^{t}\right)$ for $i \in\left[0, N\left(s^{t}\right)\right]$, and the $i_{\text {th }}$ foreign intermediate good price at home $P_{f}\left(i, s^{t}\right)$ for $i \in X^{*}\left(s^{t}\right)$, a home final good producer chooses inputs $y_{h}^{d}\left(i, s^{t}\right)$ for $i \in\left[0, N\left(s^{t}\right)\right]$, and $y_{f}^{d}\left(i, s^{t}\right)$ for $i \in X^{*}\left(s^{t}\right)$ to maximize profits,

(5) $\Pi_{F}\left(s^{t}\right)=\max \left\{P\left(s^{t}\right) D\left(s^{t}\right)-\int_{0}^{N\left(s^{t}\right)} P_{h}\left(i, s^{t}\right) y_{h}^{d}\left(i, s^{t}\right) d i-\int_{i \in X^{*}\left(s^{t}\right)} P_{f}\left(i, s^{t}\right) y_{f}^{d}\left(i, s^{t}\right) d i\right\}$,

subject to the production technology (4). Solving the problem in (5) gives the input demand functions,

$$
\begin{aligned}
& y_{h}^{d}\left(i, s^{t}\right)=\lambda^{\frac{1}{1-\rho}}\left[\frac{P_{h}\left(i, s^{t}\right)}{P_{h}\left(s^{t}\right)}\right]^{\frac{1}{\theta-1}}\left[\frac{P_{h}\left(s^{t}\right)}{P\left(s^{t}\right)}\right]^{\frac{1}{\rho-1}} D\left(s^{t}\right), i \in\left[0, N\left(s^{t}\right)\right], \\
& y_{f}^{d}\left(i, s^{t}\right)=(1-\lambda)^{\frac{1}{1-\rho}}\left[\frac{P_{f}\left(i, s^{t}\right)}{P_{f}\left(s^{t}\right)}\right]^{\frac{1}{\theta-1}}\left[\frac{P_{f}\left(s^{t}\right)}{P\left(s^{t}\right)}\right]^{\frac{1}{\rho-1}} D\left(s^{t}\right), i \in X^{*}\left(s^{t}\right),
\end{aligned}
$$

where $P_{h}\left(s^{t}\right)=\left[\int_{0}^{N\left(s^{t}\right)} P_{h}\left(i, s^{t}\right)^{\frac{\theta}{\theta-1}} d i\right]^{\frac{\theta-1}{\theta}}$, and $P_{f}\left(s^{t}\right)=\left[\int_{i \in X^{*}\left(s^{t}\right)} P_{f}\left(i, s^{t}\right)^{\frac{\theta}{\theta-1}} d i\right]^{\frac{\theta-1}{\theta}}$. The zero- 
profit condition in the perfectly competitive market determines the price level of the final good as

$$
P\left(s^{t}\right)=\left[\lambda^{\frac{1}{1-\rho}} P_{h}\left(s^{t}\right)^{\frac{\rho}{\rho-1}}+(1-\lambda)^{\frac{1}{1-\rho}} P_{f}\left(s^{t}\right)^{\frac{\rho}{\rho-1}}\right]^{\frac{\rho-1}{\rho}} .
$$

We focus on these ideal price indices rather than the average price proposed by Ghironi and Melitz (2005) as Alessandria and Choi (2007) show that empirically the movements in and out of exporting are not sufficient to lead to a large gap between these two measures in the data. Moreover, we are more focused on counts of participation over the cycle which are not influenced much by these measurement concerns.

\section{Intermediate Good Producers}

An intermediate good producer can sell its product costlessly in its own market. However, it is costly to sell its product abroad. Intermediate good producers that export to the foreign country face two types of international trading costs. To enter the foreign market, an intermediate good producer has to pay a (relatively) high initial entry cost $f_{0}\left(s^{t}\right)$. This permits the producer to export in the current period. From the following period on, to continue exporting, the producer has to pay a lower but nonzero continuation costs $f_{1}\left(s^{t}\right)\left(<f_{0}\left(s^{t}\right)\right)$. In our current specification, we will assume these costs are measured in foreign labor units augmented by foreign country-specific productivity $A^{*}\left(s^{t}\right) .{ }^{20}$ Thus, an intermediate good producer faces the fixed costs of exporting as

$$
f_{0}\left(s^{t}\right)=\overline{f_{0}} e\left(s^{t}\right)\left[\frac{W^{*}\left(s^{t}\right)}{A^{*}\left(s^{t}\right)}\right], \quad f_{1}\left(s^{t}\right)=\overline{f_{1}} e\left(s^{t}\right)\left[\frac{W^{*}\left(s^{t}\right)}{A^{*}\left(s^{t}\right)}\right]
$$

where $\overline{f_{0}}$ and $\overline{f_{1}}$ are positive constants. Since the trade costs depend on the export status of the producers last period, the total amount of export costs paid by domestic exporters equals

$$
G\left(s^{t}\right)=\int_{i \in X\left(s^{t}\right)}\left\{f_{0}\left(s^{t}\right)\left[1-m\left(i, s^{t-1}\right)\right]+f_{1}\left(s^{t}\right) m\left(i, s^{t-1}\right)\right\} d i
$$

\footnotetext{
${ }^{20}$ Paying fixed exporting costs in home labor units instead of foreign labor units does not change the results qualitatively. In the sensitivity analysis, we will consider this case and the case without the shocks to fixed costs.
} 
where $m\left(i, s^{t}\right)$ is an indicator function denoting the export status of the $i_{\text {th }}$ intermediate good producer in $s^{t}$. Here $m\left(i, s^{t}\right)=1$ if the $i_{\text {th }}$ foreign intermediate good producer is an exporter in $s^{t}$, 0 otherwise. These trade costs imply that only some,

$$
N_{X}^{*}\left(s^{t}\right)=\int_{0}^{N^{*}\left(s^{t}\right)} m^{*}\left(i, s^{t}\right) d i
$$

of foreign intermediate goods are available to home final good producers in state $s^{t}$.

An intermediate good establishment produces its differentiated good with a Cobb-Douglas production technology,

$$
F\left(i, s^{t}\right)=A\left(s^{t}\right) a\left(i, s^{t}\right) k\left(i, s^{t-1}\right)^{\alpha} l\left(i, s^{t}\right)^{1-\alpha}=y_{h}\left(i, s^{t}\right)+y_{h}^{*}\left(i, s^{t}\right)
$$

where $y_{h}\left(i, s^{t}\right)$ and $y_{h}^{*}\left(i, s^{t}\right)$ are the amounts of good $i$ sold in the home and foreign intermediate goods markets, respectively, and $k\left(i, s^{t-1}\right)$ and $l\left(i, s^{t}\right)$ are the capital and labor inputs of the establishment $i$. Capital used in production is augmented by investment of final goods, $v\left(i, s^{t}\right)$. The law of motion for capital is given by

$$
k\left(i, s^{t}\right)=(1-\delta) k\left(i, s^{t-1}\right)+v\left(i, s^{t}\right)
$$

where $\delta$ is the depreciation rate.

The term $a\left(i, s^{t}\right)$ denotes the establishment-specific productivity of the $i_{\text {th }}$ establishment. The establishment-specific productivity is independently, identically distributed across countries, establishments, and time, $\ln a\left(i, s^{t}\right) \stackrel{i i d}{\sim} N\left(0, \sigma_{a}^{2}\right)$. While the iid assumption is restrictive relative to recent work on the cyclical movements in entry (Lee and Mukoyama, 2015; or Clementi and Palazzo, 2016) it makes the distribution of capital, productivity, and exporting a finite dimensional object. Alessandria and Choi (2007) show that the iid model behaves similar to a model with producers with a persistent idiosyncratic component. In our sensitivity section we consider how the properties of the model vary with a persistent component to productivity.

The country-specific productivity $A\left(s^{t}\right)$ may be correlated across countries and evolves according to a vector autoregressive process (VAR) with the foreign country-specific productivity, 
$A^{*}\left(s^{t}\right)$,

$$
Z\left(s^{t}\right)=M Z\left(s^{t-1}\right)+\varepsilon\left(s^{t}\right), \varepsilon\left(s^{t}\right) \stackrel{i i d}{\sim} N(0, \Omega)
$$

where $M$ is a coefficient matrix; $Z\left(s^{t}\right)=\left[\ln A\left(s^{t}\right), \ln A^{*}\left(s^{t}\right)\right]^{\prime}$ and $\varepsilon\left(s^{t}\right)=\left[\epsilon\left(s^{t}\right), \epsilon^{*}\left(s^{t}\right)\right]^{\prime}$.

Consider the problem of a home intermediate good producer with the establishment-specific productivity $a\left(i, s^{t}\right)=a$, capital stock $k\left(i, s^{t-1}\right)=k$, and the export status $m\left(i, s^{t-1}\right)=m$ in state $s^{t}$. The intermediate good producer chooses current prices $P_{h}\left(i, s^{t}\right), P_{h}^{*}\left(i, s^{t}\right)$, inputs of labor $l\left(i, s^{t}\right)$, investment $v\left(i, s^{t}\right)$ and the export decision $m\left(i, s^{t}\right)=m^{\prime}$ to solve

$$
\begin{aligned}
V\left(a, k, m, s^{t}\right)= & \max \left\{\Pi_{h}\left(a, k, m ; s^{t}\right)+m^{\prime} \Pi_{h}^{*}\left(a, k, m ; s^{t}\right)\right. \\
& +\left(1-n_{d}\right) \int_{s^{t+1}} \int_{a^{\prime}} Q\left(s^{t+1} \mid s^{t}\right) \phi\left(a^{\prime}\right) V\left(a^{\prime}, k^{\prime}, m^{\prime} ; s^{t+1}\right) d a^{\prime} d s^{t+1} \\
& \left.+n_{d} \int_{s^{t+1}} Q\left(s^{t+1} \mid s^{t}\right) k^{\prime} d s^{t+1}\right\}
\end{aligned}
$$

$$
\begin{aligned}
& \Pi_{h}\left(a, k, m ; s^{t}\right)=P_{h}\left(i, s^{t}\right) y_{h}\left(i, s^{t}\right)-P\left(s^{t}\right) W\left(s^{t}\right) l\left(i, s^{t}\right)-P\left(s^{t}\right) v\left(i, s^{t}\right), \\
& \Pi_{h}^{*}\left(a, k, m ; s^{t}\right)=e\left(s^{t}\right) P_{h}^{*}\left(i, s^{t}\right) y_{h}^{*}\left(i, s^{t}\right)-\left[m f_{1}\left(s^{t}\right)+(1-m) f_{0}\left(s^{t}\right)\right],
\end{aligned}
$$

subject to the production technology (12), the law of motion for capital (13), and the constraints that supplies to home and foreign intermediate goods market $y_{h}\left(i, s^{t}\right)$ and $y_{h}^{*}\left(i, s^{t}\right)$ are equal to demands by home and foreign final good producers $y_{h}^{d}\left(i, s^{t}\right)$ and $y_{h}^{d *}\left(i, s^{t}\right)$ from (6) and its foreign analogue. Here, $\phi\left(a^{\prime}\right)$ denotes the probability of an idiosyncratic shock $a^{\prime}$. If a producer receives the death shock, it sells its capital stock $k$ and shuts down without any production but the capital is not re-allocated within the period.

Let the value of the $i_{\text {th }}$ producer if it exports in $s^{t}$ be

$$
\begin{aligned}
V^{1}\left(a, k, m ; s^{t}\right)= & \max \left\{\Pi_{h}\left(a, k, m ; s^{t}\right)+\Pi_{h}^{*}\left(a, k, m ; s^{t}\right)\right. \\
& +\left(1-n_{d}\right) \int_{s^{t+1}} \int_{a^{\prime}} Q\left(s^{t+1} \mid s^{t}\right) \phi\left(a^{\prime}\right) V\left(a^{\prime}, k^{\prime}, 1, s^{t+1}\right) d a^{\prime} d s^{t+1} \\
& \left.+n_{d} \int_{s^{t+1}} Q\left(s^{t+1} \mid s^{t}\right) k^{\prime} d s^{t+1}\right\}
\end{aligned}
$$


and let the value of the $i_{\text {th }}$ producer if it does not export in $s^{t}$ be

$$
\begin{aligned}
V^{0}\left(a, k, m ; s^{t}\right)= & \max \left\{\Pi_{h}\left(a, k, m ; s^{t}\right)\right. \\
& +\left(1-n_{d}\right) \int_{s^{t+1}} \int_{a^{\prime}} Q\left(s^{t+1} \mid s^{t}\right) \phi\left(a^{\prime}\right) V\left(a^{\prime}, k^{\prime}, 0, s^{t+1}\right) d a^{\prime} d s^{t+1} \\
& \left.+n_{d} \int_{s^{t+1}} Q\left(s^{t+1} \mid s^{t}\right) k^{\prime} d s^{t+1}\right\},
\end{aligned}
$$

Then, the actual value of $i_{\text {th }}$ producer can be defined as

$$
V\left(a, k, m, s^{t}\right)=\max \left\{V^{1}\left(a, k, m, s^{t}\right), V^{0}\left(a, k, m, s^{t}\right)\right\}
$$

Clearly the value of a producer depends on its export status, and is monotonically increasing and continuous in $a$. Moreover $V^{1}$ intersects $V^{0}$ from below only once. ${ }^{21}$ Hence, it is possible to solve for the establishment-specific productivity at which a establishment is indifferent between exporting or not exporting; that is, the increase in establishment value from exporting equals the cost of exporting. This level of technology differs by the establishments current export status. The critical level of technology for exporters and nonexporters, $a_{1}\left(s^{t}\right)$ and $a_{0}\left(s^{t}\right)$, satisfy

$$
\begin{aligned}
& V^{1}\left(a_{1}\left(s^{t}\right), k, 1, s^{t}\right)=V^{0}\left(a_{1}\left(s^{t}\right), k, 1, s^{t}\right) \\
& V^{1}\left(a_{0}\left(s^{t}\right), k, 0, s^{t}\right)=V^{0}\left(a_{0}\left(s^{t}\right), k, 0, s^{t}\right) .
\end{aligned}
$$

Among last period exporters, only those with productivity greater than $a_{1}\left(s^{t}\right)$ will continue to export in state $s^{t}$. Likewise, the critical technology of a nonexporter is denoted by $a_{0}\left(s^{t}\right)$. The decision to export will also depend on the capital stock. However, owing to the iid idiosyncractic shocks a producer's capital stocks only depend on its lagged export status, thus there is only one cutoff per type.

\footnotetext{
${ }^{21}$ If the difference between $f_{0}$ and $f_{1}$ is very large, $V^{1}>V^{0}$ for all $\ln a \in(-\infty, \infty)$ for some $s^{t}$. Since the data show that some of the previous exporters exit from foreign markets each period, it is assumed throughout that the shocks are small enough that this does not occur.
} 


\section{Entrants}

In each period, new intermediate good producers can be created by incurring a fixed cost $f_{E}\left(s^{t}\right)$. Similar to the export costs, the entry cost is measured in domestic labor units augmented with country-specific productivity,

$$
f_{E}\left(s^{t}\right)=\overline{f_{E}}\left[\frac{W\left(s^{t}\right)}{A\left(s^{t}\right)}\right]
$$

An establishment incurs the entry cost one period before its production. Once the entry cost is incurred, establishments newly accumulate capital before the realization of the establishmentspecific productivity. In the beginning of the next period, establishments receive an idiosyncratic productivity shock from the distribution which is the same as incumbents, $\phi(a)$. All the entrants face the same probability of death as incumbents. As the entrants did not export last period, the entry condition is given as

$$
\begin{aligned}
V^{E}\left(s^{t}\right)= & \max _{k_{E}}\left\{-f_{E}\left(s^{t}\right)-P\left(s^{t}\right) k_{E}\left(s^{t}\right)+n_{d} \int_{s^{t+1}} Q\left(s^{t+1} \mid s^{t}\right) k_{E}\left(s^{t}\right) d s^{t+1}\right. \\
& \left.+\left(1-n_{d}\right) \int_{s^{t+1}} \int_{a^{\prime}} Q\left(s^{t+1} \mid s^{t}\right) \phi\left(a^{\prime}\right) V\left(a^{\prime}, k_{E}\left(s^{t}\right), 0, s^{t+1}\right) d a^{\prime} d s^{t+1}\right\} \geq 0
\end{aligned}
$$

where $k_{E}\left(s^{t}\right)$ is the capital stock chosen by new establishments. As an entrant starts the next period as a non-exporter it will choose a capital stock equal to that of incumbent non exporter, $k_{0}\left(s^{t}\right)$.

This equation makes clear what is needed to for entry to be procyclical. Following a positive shock, at the old level of entry we either need the cost of entry (the first term) to fall or the expected value net of investment to rise. Obviously, in an equilibrium with entry this equation will hold with equality. International trade will generate more procyclical entry by allowing the entry cost to fall by more and the expected value of entering to rise by more.

Let the mass of entrants who pay the entry cost in $s^{t}$ be $N_{E}\left(s^{t}\right)$, while the mass of incumbents be $N\left(s^{t}\right)$. As only $\left(1-n_{d}\right)$ fraction of incumbents and entrants survives the next period, the mass of producers evolves as

$$
N\left(s^{t}\right)=\left(1-n_{d}\right)\left[N\left(s^{t-1}\right)+N_{E}\left(s^{t-1}\right)\right] .
$$


Let the mass of nonexporters be

$$
N_{N}\left(s^{t}\right)=N\left(s^{t}\right)-N_{X}\left(s^{t}\right)
$$

The trade costs imply that only a fraction $n_{X}\left(s^{t}\right)=N_{X}\left(s^{t}\right) / N\left(s^{t}\right)$ of home intermediate goods are available in the foreign country in $s^{t}$.

From (21), (22), and the independence of the establishment-specific productivity, the fraction of exporters in $s^{t}$ among survived exporters in $s^{t-1}$ and the fraction of exporters in $s^{t}$ among survived nonexporters in $s^{t-1}, n_{1}\left(s^{t}\right)$ and $n_{0}\left(s^{t}\right)$, respectively, can be defined as

$$
\begin{aligned}
& n_{1}\left(s^{t}\right)=\frac{N_{X}\left(s^{t-1}\right) \int_{a_{1}\left(s^{t}\right)}^{\infty} \phi(a) d a}{N_{X}\left(s^{t-1}\right)}=\int_{a_{1}\left(s^{t}\right)}^{\infty} \phi(a) d a \\
& n_{0}\left(s^{t}\right)=\frac{N_{N}\left(s^{t-1}\right) \int_{a_{0}\left(s^{t}\right)}^{\infty} \phi(a) d a}{N_{N}\left(s^{t-1}\right)}=\int_{a_{0}\left(s^{t}\right)}^{\infty} \phi(a) d a .
\end{aligned}
$$

The law of motion for the masses of exporters and nonexporters are given as

$$
\begin{aligned}
& N_{X}\left(s^{t}\right)=\left(1-n_{d}\right)\left\{n_{1}\left(s^{t}\right) N_{X}\left(s^{t-1}\right)+n_{0}\left(s^{t}\right)\left[N_{N}\left(s^{t-1}\right)+N_{E}\left(s^{t-1}\right)\right]\right\} \\
& N_{N}\left(s^{t}\right)=\left(1-n_{d}\right)\left\{\left[1-n_{1}\left(s^{t}\right)\right] N_{X}\left(s^{t-1}\right)+\left[1-n_{0}\left(s^{t}\right)\right]\left[N_{N}\left(s^{t-1}\right)+N_{E}\left(s^{t-1}\right)\right]\right\}
\end{aligned}
$$

\section{A. Aggregate Variables}

The aggregate capital available in $s^{t}$ at home is defined as

$$
K\left(s^{t}\right)=\int_{0}^{N\left(s^{t}\right)} k\left(i, s^{t}\right) d i
$$

The investment, $I_{t}$, is given by the sum of individual investment less the capital stock received from dying establishments,

$$
I\left(s^{t}\right)=\int_{0}^{N\left(s^{t}\right)} v\left(i, s^{t}\right) d i+N_{E}\left(s^{t}\right) k_{E}\left(s^{t}\right)-n_{d}\left[\int_{0}^{N\left(s^{t-1}\right)} k\left(i, s^{t-1}\right) d i+N_{E}\left(s^{t-1}\right) k_{E}\left(s^{t-1}\right)\right] .
$$


Nominal exports and imports are given as

$$
\begin{aligned}
E X^{N}\left(s^{t}\right) & =\int_{i \in X\left(s^{t}\right)} e\left(s^{t}\right) P_{h}^{*}\left(i, s^{t}\right) y_{h}^{*}\left(i, s^{t}\right) d i \\
I M^{N}\left(s^{t}\right) & =\int_{i \in X^{*}\left(s^{t}\right)} P_{f}\left(i, s^{t}\right) y_{f}\left(i, s^{t}\right) d i
\end{aligned}
$$

Real exports and real imports are defined as, $E X\left(s^{t}\right)=E X^{N}\left(s^{t}\right) /\left[e\left(s^{t}\right) P_{h}^{*}\left(s^{t}\right)\right]$ and $I M\left(s^{t}\right)=$ $I M^{N}\left(s^{t}\right) / P_{f}\left(s^{t}\right)$, respectively. Nominal GDP of the home country is defined as the sum of value added from producers,

$$
Y^{N}\left(s^{t}\right)=P\left(s^{t}\right) D\left(s^{t}\right)+E X^{N}\left(s^{t}\right)-I M^{N}\left(s^{t}\right) .
$$

Real GDP is defined as $Y\left(s^{t}\right)=Y^{N}\left(s^{t}\right) / P_{h}\left(s^{t}\right)$.

The total labor used for production, $L_{P}\left(s^{t}\right)$ is given by

$$
L_{P}\left(s^{t}\right)=\int_{0}^{N\left(s^{t}\right)} l\left(i, s^{t}\right) d i
$$

Home labor hired by foreign exporters, $L_{X}^{*}\left(s^{t}\right)$, is given by

$$
L_{X}^{*}\left(s^{t}\right)=\frac{\overline{f_{1}}}{A\left(s^{t}\right)} \int_{i \in X^{*}\left(s^{t}\right)} m\left(i, s^{t-1}\right) d i+\frac{\overline{f_{0}}}{A\left(s^{t}\right)} \int_{i \in X^{*}\left(s^{t}\right)}\left[1-m\left(i, s^{t-1}\right)\right] d i,
$$

and home labor hired by new establishments, $L_{E}\left(s^{t}\right)$, is given by

$$
L_{E}\left(s^{t}\right)=\frac{\overline{f_{E}} N_{E}\left(s^{t}\right)}{A\left(s^{t}\right)}
$$

Aggregate profits are measured as the sum of profits of operating establishments and capital 
resale revenue of shutdown establishments less the costs of creating new establishments,

$$
\begin{aligned}
P\left(s^{t}\right) \Pi\left(s^{t}\right)= & \Pi_{F}\left(s^{t}\right)+\int_{0}^{N\left(s^{t}\right)}\left[\Pi_{h}\left(i, s^{t}\right)+m\left(i, s^{t}\right) \Pi_{h}^{*}\left(i ; s^{t}\right)\right] d i \\
& +n_{d}\left[\int_{0}^{N\left(s^{t-1}\right)} P\left(s^{t}\right) k\left(i, s^{t-1}\right) d i+N_{E}\left(s^{t-1}\right) P\left(s^{t}\right) k_{E}\left(s^{t-1}\right)\right] \\
& -N_{E}\left(s^{t}\right)\left[f_{E}\left(s^{t}\right)+P\left(s^{t}\right) k_{E}\left(s^{t}\right)\right] .
\end{aligned}
$$

\section{B. Equilibrium Definition}

In an equilibrium, variables satisfy several resource constraints. Market clearing in final goods requires $C\left(s^{t}\right)+I\left(s^{t}\right)=D\left(s^{t}\right)$, and $C^{*}\left(s^{t}\right)+I^{*}\left(s^{t}\right)=D^{*}\left(s^{t}\right)$. Intermediate goods market clearing conditions requires $y_{h}^{d}\left(i, s^{t}\right)=y_{h}\left(i, s^{t}\right)$ for $i \in\left[0, N\left(s^{t}\right)\right], y_{f}^{d}\left(i, s^{t}\right)=y_{f}\left(i, s^{t}\right)$ for $i \in X^{*}\left(s^{t}\right)$, $y_{f}^{d *}\left(i, s^{t}\right)=y_{f}^{*}\left(i, s^{t}\right)$ for $i \in\left[0, N\left(s^{t}\right)\right]$, and $y_{h}^{d *}\left(i, s^{t}\right)=y_{h}^{*}\left(i, s^{t}\right)$ for $i \in X^{*}\left(s^{t}\right)$. Labor market clearing requires $L\left(s^{t}\right)=L_{P}\left(s^{t}\right)+L_{E}\left(s^{t}\right)+L_{X}^{*}\left(s^{t}\right)$, and $L^{*}\left(s^{t}\right)=L_{P}^{*}\left(s^{t}\right)+L_{E}^{*}\left(s^{t}\right)+L_{X}\left(s^{t}\right)$. The profits of establishments are distributed to the shareholders, $\Pi\left(s^{t}\right)$, and the foreign analogue. International bond market clearing implies $B\left(s^{t+1}\right)+B^{*}\left(s^{t+1}\right)=0$. Finally, writing the budget constraints in units of the local currency permits us to normalize the price of consumption in each country as $P\left(s^{t}\right)=P^{*}\left(s^{t}\right)=1$.

An equilibrium of the economy is a collection of allocations for home consumers $C\left(s^{t}\right), L\left(s^{t}\right)$, $B\left(s^{t+1}\right)$; allocations for foreign consumers $C^{*}\left(s^{t}\right), L^{*}\left(s^{t}\right), B^{*}\left(s^{t+1}\right)$; allocations for home final goods producers $D\left(s^{t}\right), y_{h}^{d}\left(i, s^{t}\right)$ for $i \in\left[0, N\left(s^{t}\right)\right]$, and $y_{f}^{d}\left(i, s^{t}\right)$ for $i \in X^{*}\left(s^{t}\right)$; allocations for foreign final good producers $D^{*}\left(s^{t}\right), y_{f}^{d *}\left(i, s^{t}\right)$ for $i \in\left[0, N^{*}\left(s^{t}\right)\right]$, and $y_{h}^{d *}\left(i, s^{t}\right)$ for $i \in X\left(s^{t}\right)$; allocations and prices for home intermediate good producers $l\left(i, s^{t}\right), v\left(i, s^{t}\right), y_{h}\left(i, s^{t}\right)$, and $P_{h}\left(i, s^{t}\right)$ for $i \in\left[0, N\left(s^{t}\right)\right]$, $y_{h}^{*}\left(i, s^{t}\right)$ and $P_{h}^{*}\left(i, s^{t}\right)$ for $i \in X\left(s^{t}\right)$; allocations and prices for foreign intermediate good producers $l^{*}\left(i, s^{t}\right), v^{*}\left(i, s^{t}\right), y_{f}\left(i, s^{t}\right)$ and $P_{f}\left(i, s^{t}\right)$ for $i \in X^{*}\left(s^{t}\right), y_{f}^{*}\left(i, s^{t}\right)$ and $P_{f}^{*}\left(i, s^{t}\right)$ for $i \in\left[0, N^{*}\left(s^{t}\right)\right]$; the export statuses of home and foreign intermediate good producers $m\left(i, s^{t}\right)$ for $i \in\left[0, N\left(s^{t}\right)\right]$ and $m^{*}\left(i, s^{t}\right)$ for $i \in\left[0, N^{*}\left(s^{t}\right)\right]$; allocations of home and foreign new establishments, $k_{E}\left(s^{t}\right)$ and $k_{E}^{*}\left(s^{t}\right)$; labor used for exporting costs $L_{X}\left(s^{t}\right)$ and $L_{X}^{*}\left(s^{t}\right)$ at home and foreign; labor used for creation of new establishments $L_{E}\left(s^{t}\right)$ and $L_{E}^{*}\left(s^{t}\right)$ at home and foreign; real wages $W\left(s^{t}\right)$ and $W^{*}\left(s^{t}\right)$, nominal exchange rates $e\left(s^{t}\right)$; and bond prices $Q\left(s^{t+1} \mid s^{t}\right)$ that satisfy the following conditions: (i) the consumer allocations solve the consumer's problem; (ii) the final good producers' allocations solve their profit maximization problems; (iii) the intermediate good producers' allocations, prices, 
and export statuses solve their profit maximization problems; (iv) the entrants' allocations solve their profit maximization problems; (v) the establishment entry conditions hold; and (vi) the market clearing conditions hold.

\section{Calibration}

We now describe the parameter values considered for our benchmark economy. The parameter values used in simulation exercises are reported in Table 2 . The choice of the time discount factor, $\beta$, the rate of depreciation, $\delta$, capital's share parameter in production, $\alpha$, and risk-aversion parameter, $\sigma$, is standard in the literature, $\beta=0.96, \delta=0.10, \alpha=0.36$, and $\sigma=2$. The share parameter for consumption in the composite commodity, $\gamma$, is set to be equal to 0.383 so that people allocate $1 / 3$ of total available time to work.

The final good production parameters $\rho$ and $\theta$ determines the elasticity of substitution between composite domestic and foreign goods and the elasticity between varieties within a composite, respectively. We set $\theta=5 / 6$ which gives an establishment's markup of 20 percent. This value of $\theta$ is consistent with the elasticity estimated by Broda and Weinstein (2006). In the benchmark model, we set $\rho=0.75$ which gives the elasticity of substitution between home and foreign composite goods of 4 . In the sensitivity analysis, we consider $\theta \in[0.8,0.96]$ and $\rho \in[0,0.8]$.

The country-specific productivity process is an annualized version of that in Kehoe and Perri (2002). The shocks are persistent with an autocorrelation of 0.815 and there are no cross-country spillover. The volatility of the shock is set to be 0.013 . The correlation between home and foreign shocks are set to be 0.25 .

Establishments and capital are durable assets with different attributes. Lee and Mukoyama (2008) find the exit rate in the ASM from 1972 to 1997 is approximately 5.4 percent. Davis, Haltiwanger, and Schuh (1996) find an employment weighted exit rate of 2.3 percent per year. Since our emphasis is on the dynamics of entry and exporting over the business cycle, we would like a general equilibrium model that can reasonably replicate features of exit and entry in stocks of establishments. Thus, we set the exogenous exit rate, $n_{d}$, to be 5.4 percent. In the sensitivity analysis, we consider a wide range of the exit rate, $n_{d} \in[0.01,0.10]$. We set the sunk cost parameter, $\overline{f_{E}}$, to be 0.751 to normalize the mass of producers in a country to $1, N=1$ in the steady state. ${ }^{22}$

\footnotetext{
${ }^{22}$ We could scale this down to match any level of producers. This would then scale the fixed export costs down as
} 
The parameters $\overline{f_{0}}, \overline{f_{1}}, \lambda$, and $\sigma_{a}$ jointly determine the amount of trade, characteristics of exporters and nonexporters, the dynamics of export status and producer growth. To set these parameters, we use the following four pieces of evidence: i) a stopper rate, the fraction of nonexporters among survived last period exporters, of 17 percent as in Bernard and Jensen (1999) based on the Longitudinal Research Database (LRD) of the Bureau of the Census 1984-1992; ii) an exporter rate, the fraction of exporters among all establishments, of 21 percent based on the 1992 Census of Manufactures; iii) trade to GDP ratio, exports plus imports divided by two times of GDP, of 15 percent; and iv) exporter output premium, average output of exporters relative to average output of nonexporters in logarithm, of 103 percent based on Bernard and Jensen (1999). Choosing these parameters jointly to match these statistics yields values of $\overline{f_{0}}=0.116, \overline{f_{1}}=0.036$, $\lambda=0.566$, and $\sigma_{a}=0.450$. The calibration suggests that previous nonexporters pay about 3.2 times more than continuing exporters to export their products in the foreign market in the steady state. With these parameter values together with the sunk cost of entry, about 13 percent of labor is used for creating new variety and about 3 percent for exporting. ${ }^{23}$

In the sensitivity analysis, we vary the parameter values to match these features in the model. For instance if we set the sunk and fixed costs equal we recover a version of the static exporting model in Ghironi and Melitz (2005) in which there is no overlap in the productivity of exporters and non-exporters which thus requires a less dispersion in productivity $\left(\sigma_{a}=0.295\right.$ vs. $\sigma_{a}=0.385$ in benchmark) to generate the same exporter premium. The long run implications of shocks in these models are different. For instance, following a cut in tariffs the sunk cost model has an increasing and larger trade elasticity while the other model has a constant trade elasticity. The sunk cost model generates about 25 percent larger increase in trade in the long run. ${ }^{24}$

We focus on the effects of international trade on the dynamics of entry and exporting over the business cycle. To isolate the role of international trade on the business cycles, we also consider three alternative cases where there is no international borrowing and lending (financial autarky),

well since these are determined by shares of total producers. This would affect no moments of the model.

${ }^{23}$ The cost of creating firms is almost 7 times the cost of starting to export. This reflects the relatively closed nature of the economy as domestic sales are almost six times foreign sales and the fact the profits from these sales are a return on these investments in producer and exporter creation.

${ }^{24}$ The trade elasticity measures the change in the ratio of expenditures on imports to domestic goods to the change in a trade barrier. The sunk cost model generates a trade elasticity of 8.11 while with only a fixed cost this elasticity is 6.42 while with no extensive margin of trade it is 4 . 
no trade across countries (closed economy), and no fixed costs in exporting.

In general, keeping track of distributions over productivity and capital of producers is computationally difficult. However, the iid assumption in firm-specific productivity shocks greatly simplifies the analysis. As producers are either exporters or nonexporters with the same expectation about their next period firm-specific productivity, at any point in time producers will choose either a relatively low capital stock for the next period if they do not export today, or a relatively high capital stock for the next period if they do export today. Consequently, the distribution of the capital stock at home is completely summarized by the capital stock of exporters and nonexporters, $K_{1}\left(s^{t-1}\right)$ and $K_{0}\left(s^{t-1}\right)$, and the masses of exporters and nonexporters, $N_{X}\left(s^{t-1}\right)$ and $N_{N}\left(s^{t-1}\right)$. Similarly the foreign capital stock distribution is completely described by $K_{1}^{*}\left(s^{t-1}\right), K_{0}^{*}\left(s^{t-1}\right)$, $N_{X}^{*}\left(s^{t-1}\right)$ and $N_{N}^{*}\left(s^{t-1}\right)$. With these summary statistics for the distributions of capital stocks together with the properties of lognormality for the integration over establishments, we solve the model by log-linearization. The models are simulated for 1000 times with 100 periods.

\section{Results}

In this section, we examine the properties of the benchmark model. We first examine the properties of establishment dynamics. Then, we investigate the predictions of business cycles in the benchmark model. Lastly, we study the impulse response of major variables following a countryspecific productivity shock at home.

\section{Establishment employment dynamics}

The model captures some salient features on the evolution of employment at the establishmentlevel. Namely, establishments start out small and grow over time and exporters tend to be relatively big, but over time their employment growth lags that at non-exporters (Bernard and Jensen 2004).

Figure 4 plots the steady state average employment relative to overall employment by export status and entry at the initial period. Entrants start out with 6.9 percent fewer workers than the average producer. Among these entrants, over time productive establishments become exporters and unproductive establishments remain as nonexporters. As time progresses more establishments from a cohort start exporting and the average employment level and capital stock increases toward that of the average incumbents by year 5 . While qualitatively consistent with the dynamics of entrants, our entrant is larger than the typical US entrant in the US which starts about half as large as an 
incumbent but also takes about 5 years to reach the average scale (Clementi and Palazzo, 2016). In our sensitivity section we consider an extension that more closely matches the scale and growth of entrants.

Initially nonexporters have a very low level of employment on average since they are unproductive and many of them have a low level of capital. The average employment of the initial nonexporters is about 27.7 percent lower than the overall average. From the following period, establishments that stop exporting due to low productivity receive a new productivity level drawn from the same distribution as other types of establishments. Thus, average employment becomes very close to that of entrants, although the average employment is slightly lower than that of the initial entrants as the exporter ratio of initial nonexporters is lower than that of initial entrants. Similar to the entrants, the average employment of the initial nonexporters increases toward the average level of incumbents.

The initial continuing exporters have about 48.8 percent higher level of employment relative to the average employment since continuing exporters have a high level of capital, access more markets and have higher average productivity from selection. In the following period, some of these initial exporters receive bad productivity shocks and stop exporting. With this exit from the foreign market, the establishments reduce their capital stock and their average size drops. From then on, the exporter ratio within this group converges toward the exporter ratio of incumbents, and the employment level diminishes toward the average employment level of incumbents.

The dashed line denoted Initial Exporters shows that the model generates a large but temporary selection effect on exporting. Initially, the employment level of entrants into exporting is higher than that of continuing exporters. In the following period, the productivity level of this group becomes the same as that of initial continuing exporters. Also, the exporter ratios of these two groups are the same with iid productivity.

\section{Business cycles}

We now consider the aggregate properties of entry, importing, and exporting over the business cycle. The column dubbed Benchmark in Table 3 shows the benchmark model captures some of the key business cycle properties of the stock of establishments, importers, and exporters. ${ }^{25}$ In

\footnotetext{
${ }^{25}$ All the variables are H-P filtered with the smoothing parameter of 6.25 after taking logarithm.
} 
terms of volatility, the model generates fluctuations in exporters and importers relative to output of 1.46, similar to the data, where they are 1.48 and 1.30, respectively. The stock of establishments fluctuates slightly more in the model than the data (0.77 vs. 0.50). The model also qualitatively matches the cyclicality of establishments and traders. The stock of establishment is procyclical (correlation with output of 0.25 in the model and 0.47 in the data). Importers are more procyclical, with a correlation with output of 0.59 (0.61 in the data). However, in the model, the exporters are procyclical while in the data they are countercyclical (0.13 vs. -0.08). The model understates the volatility and procyclicality of trade. ${ }^{26}$

One key feature of the data is that the stock of establishments is positively correlated with importers whereas it is negatively correlated with exporters. The model also predicts positive relationship between the stock of establishments and importers with the correlation of 0.07 ( 0.31 in the data), although the model predicts no correlation between the stock of establishments and exporters. The correlation in the model is -0.00 (-0.28 in the data). Overall, from productivity shocks alone, the benchmark model generates fluctuations in the stock of establishments, exporters, and importers that are similar to those in the data.

\section{Impulse-responses}

To examine the dynamics of the economy, we plot the responses of key variables to a one-time one standard deviation positive country-specific productivity shock at home in Figures 5 and 6 . The first figure plots the dynamics of entry and the stock of establishments in home and foreign. When there is a positive shock at home, there is a large increase in the creation of new establishments of 14.6 percent at the initial period. Over time, the incentive to create new establishment falls. After 4 years, entry falls below the initial steady state level. From the 8th year following the shock, the mass of entrants rises toward the steady state level. With the rise and fall in entrants, the stock of producers in the domestic country rises for 4 years and then gradually falls toward its long run level. The stock of importers also rises initially by more than the stock of domestic establishments. The rise in importers is less persistent and falls below the steady state level after three periods. These dynamics of entry suggest that initially entry by importers is complementary to entry by

\footnotetext{
${ }^{26}$ The model inherits both the successes and failures of the international RBC model of Backus, Kehoe and Kydland (1994). In particular, the model fails to generate relative price fluctuations of the appropriate magnitudes.
} 
domestic establishments, while in the long-run, entry by domestic establishments substitutes for that by importers. In contrast to the dynamics of entry, the stock of exporters rises gradually from the initial period for 7 years. These increases in exporting reflect both the greater value of exporting of domestic establishments from being more productive and reduced competition overseas from a contraction in the stock of establishments.

The second figure depicts the typical macroeconomic aggregates studied in international business cycle models. As is normal, risk-sharing leads consumption to rise in both countries and a shift in production and investment towards the relatively more productive country. However, unlike a model without entry, the dynamics of investment and output are hump-shaped, peaking in the fourth year. ${ }^{27}$ These hump-shaped dynamics reflect hump-shaped dynamics of labor used in production and is evident in other models with endogenous entry (Cook, 2001; and Clementi and Palazzo, 2016). Initially, labor is more productively used in the creation of establishments and the stock of exporters. Once these forms of organizational capital are accumulated, labor can be more effectively used in the production of goods. Thus, we see that investment in organizational capital precedes investment in physical capital.

\section{Sensitivity}

To clarify the source of dynamics in the stock of establishments we now consider a series of alternate models. First, we examine the importance of international trade by imposing restrictions on intertemporal and intratemporal international trade. Second, we study how the structure of fixed costs, both in terms of the size and market of export costs are incurred and their cyclicality, influence the cyclicality in the stock of domestic establishments. Third, we bring the cyclicality of trade closer to the data by allowing variable trade costs to vary over the cycle with the aggregate productivity shocks. Fourth, we vary the exit rate to examine the influence of the durability of investment in entry relative to exporting or physical capital accumulation for the model's properties. Fifth, we examine the sensitivity of the model to the substitutability of goods within and across countries. Finally, we show our results are robust to extensions that better capture the lifecycle of new producers and importance of new exporters.

\footnotetext{
${ }^{27}$ Cogley and Nason (1995) emphasize that standard real business cycle models lack a strong internal propogation mechanism compared to the data.
} 


\section{International Trade}

To isolate the role of international trade on the dynamics of the stock of establishments, we consider two ways international trade can matter. Specifically, we first consider a world with no international trade (closed economy) and then one with no international borrowing and lending (financial autarky). The results are reported in columns Closed economy and Financial autarky of Table 3.

Without international trade, the stock of establishments is less volatile (0.55 vs. 0.77 ) and acyclical (-0.01 vs. 0.25) compared to the benchmark model. This acyclical entry in the closed economy occurs despite the shocks to entry cost. Without trade when the domestic economy has a positive productivity innovation, it can not use foreign varieties to build up its capital stock and thus must devote more resources itself to physical investment. This bids the wage rate up by more, increasing the cost of creating establishments. Additionally, since domestic establishments only sell at home, the expected value of entering rises by less.

Figure 7 compares the dynamics of output in the closed economy against the open economy. Here we see that the open economy generates a much larger hump in output than the closed economy. The larger and more delayed expansion increases the expected value of entering. Taken together, entry becomes both smoother and countercyclical.

With financial autarky, the current account always equals zero. Thus, when a country experiences a positive productivity shocks and wants to accumulate capital, it can not do so by borrowing from abroad. This dampens the output expansion as shown in Figure 7 and also pushes up the interest rate. Both features reduce the benefit of entering in a boom making the stock of establishment acyclical. Additionally, international trade is less volatile compared to the benchmark model. With this limitation, the number of exporters becomes about 35 percent as volatile as that under benchmark case and the stock of establishment fluctuates by 44 percent less. The stock of domestic establishments is more stable because, with the limited intertemporal trade, the expected gains from creating a new establishment becomes less variable as the expansion of sales through entering foreign markets are more limited. Limiting asset trade makes exporters and importers overly procyclical and too smooth. 


\section{Nature and Types of Fixed Costs}

We now consider some variations in the nature and types of fixed costs. First we show that having a sunk export cost, as is common in structural trade models, leads the model to more closely match the data on export, import, and domestic activities over the cycle. Second, we show that allowing the fixed costs to vary over the cycle generates substantially more volatility in domestic establishments. Third, we show that establishment volatility and cyclicality is more in line with the data and smaller shocks to entry costs are necessary when we introduce a cost of serving the domestic market.

We first consider an open economy with no fixed export costs. In this case, all producers also export making all varieties available in both countries. The decision to export is bundled with the decision to create a product. The results are shown in the column No fixed export costs. The stock of establishment is slightly less volatile (0.61 vs. 0.77 in the benchmark) and strongly procyclical (0.92 vs. 0.25 in the benchmark), whereas the importers are less volatile (0.61 vs. 1.46 in the benchmark) and acyclical (0.02 vs. 0.59 in the benchmark). The stock of establishments and importers become negatively related (-0.08). With no separate export decision, a newly created establishment automatically enters the foreign market without incurring any costs. Thus, there is a strong incentive to create new establishments when there is a positive shock at home. On the other hand, the foreign country reduces the stock of establishments as the demand for goods fall in the foreign country following a positive home country shock. With this strong procyclicality, the stock of establishments is negatively related to importers.

In the column No sunk export cost we consider a variation in which exporting is a static decision by making the entry export cost equal the continuation cost. ${ }^{28}$ This lowers the volatility of domestic establishment about 5 percent below our benchmark. Moreover, counter to the data exporters are strongly procyclical and positively correlated with domestic establishments while importers are negatively correlated with domestic establishments. Moreover, the extensive margin of trade responds too much. These features reflect the ease in which exporters and importers can quickly enter and exit the market unlike as in the sunk cost model.

Next we consider the assumption that fixed export costs vary with the entry costs and

\footnotetext{
${ }^{28}$ The static exporting model has been studied by Ghironi and Melitz (2005) without capital and Fattal-Jaef and Ignacio-Lopez (2014) with capital.
} 
productivity. Specifically, we assume that a continuing exporter and new exporter have to hire $\overline{f_{0}}$ and $\overline{f_{1}}$ units of foreign workers, respectively, all the time. Thus, the productivity level does not affect the required labor for exporting. The simulation results are reported in the column No shocks to export costs. Eliminating the shocks to export costs primarily affects the volatility and cyclicality of establishments actively trading and trade. The volatility of exporters relative to that of output falls from 1.46 to 0.69 and trade becomes much smoother, falling from 2.00 to 1.08. The volatility of the establishment stock falls to a level similar to our closed economy case $(0.55)$. Without shocks to export costs, a rise in productivity raises the wage rate of the country, raising the cost of entry by foreign exporters, making the mass of foreign exporters (home importers) countercyclical (-0.41 vs. 0.59 in the benchmark model) and less correlated with the stock of domestic establishment $(-0.21$ vs. 0.07 in the benchmark model)

Now we assume that there are no shocks to neither the fixed export or entry costs (No shocks to all costs). Without any shocks to fixed costs, the volatility of exporters rises to 0.96, and the stock of establishments becomes very stable (0.10). Without the shocks, it becomes more costly to create establishments in good times as the wage rate rises but the establishment creation technology remains the same with a positive shock at home. With less investment in the creation of establishments in the foreign country, the foreign wage rate does not rise as much as the case with shocks to sunk costs of entry. Thus, more establishments in the home country find it profitable to enter the foreign market following a positive shock at home, making the mass of exporters procyclical with the correlation between exporters and output of 0.25 . At the same time, more foreign producers enter the home country as the home wage rate does not rise by as much with less use of workers in creating establishments. Thus, importers also becomes procyclical with the correlation of 0.32 . Due to these dynamics, the stock of establishments and exporters are negatively correlated (-0.16), and the stock of establishments and importers are essentially uncorrelated (-0.02). If we eliminate the shocks to just entry costs (No shocks to entry costs) but keep the shocks to export costs we still have procyclical entry but the stock does not change much. As shown in Figure 7, the immediate response to the home productivity shock is smilar to the open economy real business cycle model without entry, but it is less persistent due to the dynamcis of stock of establishments, exporters and importers.

We now alter the denomination of export costs so they now depend on efficiency units in the 
source market (Export costs in home labor). These shocks lead the costs of exporting to fall with the cost of producer entry following a good shock. This encourages more entry following a good shock increasing the volatility and procyclicality of entry to 0.29 . With the larger increase in entry, exporting and importing become slightly less procyclical.

Our final variation of fixed costs is to introduce a per-period cost of domestic production, $f_{C}<f_{E}$. These types of overhead costs are common in heterogeneous producer models based on Hopenhayn (1992). This overhead cost lowers the period net profit but does not generate any exit owing to its small size and the iid nature of productivity shocks. ${ }^{29}$ By lowering the net profits from domestic sales this makes entry substantially more volatile. We set $f_{C} / f_{E}$ to equal 10 percent and scale down the effect of the domestic productivity shock on entry costs by $1 / 3$ so that entry is about as volatile as in our benchmark model. The results are reported in the column Overhead Costs. Overhead costs make entry more procyclical (0.41 vs. 0.25 in the benchmark) and exporting and importing slightly less procyclical (0.10 vs. 0.13 and 0.53 vs. 0.59 ). The comovement of foreign market participation with domestic participation is now closer to the data as exporting is now negatively correlated with establishments and importing is positively correlated.

\section{Cyclicality of International Trade}

The current model misses out on some aspects of trade flows in that they are neither volatile nor procyclical enough. Thus, in good times home entrants face too little competition from foreign firms and existing home firms don't expand strongly enough into foreign markets. We show that by bringing these trade flows in line with the data we reduce the procyclicality and volatility of entry but increase the procyclicality of importing and exporting.

We now introduce a variable cost of importing that moves countercyclically as documented by Levchenko, Lewis and Tesar (2010) and Alessandria, Kaboski and Midrigan (2011, 2013). ${ }^{30}$ Specifically, we allow the cost of importing to the home (foreign) country, $\tau_{t}\left(\tau_{t}^{*}\right)$, to depend on

\footnotetext{
${ }^{29}$ With $f_{C}<f_{E}$ and iid shocks no producer would exit since it is cheaper to remain active than create a new producer who would start the next period with the same expected productivity. With persistent productivity shocks a producer might exit if its expected productivity was sufficiently below that of an entrant.

${ }^{30}$ These papers show that imports tend to fall too much in recessions given the movements in relative prices and final spending on tradables or foreign goods. They denote this gap as being a trade wedge and attribute it to either a rise in the costs of importing or a fall in the taste for foreign goods. As these are isomorphic in the models, we focus on cyclical changes in trade costs.
} 
foreign productivity and vice versa,

$$
\tau_{t}=\bar{\tau} e^{-\zeta z_{t}^{*}} \text { and } \tau_{t}^{*}=\bar{\tau} e^{-\zeta z_{t}}
$$

where $\bar{\tau}$ is the average trade cost. ${ }^{31}$

The scale parameter, $\zeta$, is set to match the cyclicality of trade flows. Setting $\zeta$ to move $1 / 4$ as much as foreign productivity boosts the volatility of trade flows to slightly above that observed in the data and makes both imports and exports more procyclical with a gap close to that in the data. Now more output growth comes through foreign expansion. Since new producers discount the benefit of foreign markets strongly owing to the sunk cost they mostly face more import competition, which now is more persistent than in the benchmark model. These changes reduce the correlation of producers with GDP from 0.25 to 0.22 but raises the procyclicality of importing and exporting.

\section{Durability of entry}

We now consider how the properties of establishments influence the properties of the model. We start by examining the influence of establishment durability for the model properties. To do so, we allow the annual exit rate (probability of death) to vary from 1 percent to 10 percent. The results are summarized in the panel of Figure 8. Panel A shows how the steady state labor allocated to creation of establishments and exporters varies with the exit rate. The use of labor for exporting is not sensitive to the exit rate. However, the use of labor in creating a new establishment is quite sensitive to the exit rate. As we increase the exit rate from 1 percent to 10 percent, the labor used by new exporters increases by 0.9 percentage points and the labor used by continuing exporters falls by 0.6 percentage points. However, the labor used for creating new establishments rises by 10.8 percentage points. In the steady state, the ratio of new establishments relative to all establishments is given as $n_{d} /\left(1-n_{d}\right)$. Thus, as we increase the exit rate, more establishments should be created in the steady state, and more of labor should be used for creating new establishments. However, since we maintain the same exporter ratio and the fraction of exporters that stop exporting next period, total labor used for exporting remains quite stable across a wide range of exit rates.

Panel B shows that the volatility of exporters and establishments rises with the exit rate.

\footnotetext{
${ }^{31}$ Given our the taste parameter from our Armington demand structure this is effectively a normalization.
} 
With a high exit rate, investments in establishments or exporters are less durable, so the ratio of entrants to incumbents is quite high. Thus, when there are shocks to the economy, an increase in new exporters or establishments will have a greater effect on stock of exporters or establishments.

The exit rate also influences the correlation of the stock of domestic establishments with importers, exporters, and output (Panel C). As we raise the exit rate, the stock of domestic establishments becomes strongly procyclical and importers become strongly correlated with domestic entry. Thus, with high exit rates, the gain from the low costs of creating establishments or importers spurs substantial entry in the same market. With a very low exit rate, importers become negatively correlated with domestic establishments since there is very little incentive to increase variety through a persistent investment in the stock of less productive establishment when the same resources can be used to persistently raise the stock of relatively more productive establishments. Similarly, with the low exit rate, the stock of domestic establishments is positively correlated with exporters, since investments in exporting will be more durable.

\section{Armington elasticity}

Here we examine the role of the substitutability of goods within and across countries. These elasticities affect our model in two ways. First, the elasticity of substitution between goods that are produced in a same country, $1 /(1-\theta)$, is directly linked to the markup of producers and hence the incentive to export and create establishments. Second, the elasticity of substitution indirectly affects the economy through its effect on the marginal value of an additional variety, since with the same amount of resources you can produce more goods (see Benassy, 1996). The variety effect is determined by the elasticity of substitution in the CES final good production function and decreases with the elasticity of substitution. ${ }^{32}$

Consider first the effect of the elasticity of substitution between goods within a country. Figure 9 summarizes the results for $\theta \in[0.80,0.96]$. The volatility of stock of domestic establishments is not sensitive to the elasticity of substitution while the stock of exporters becomes less volatile as we raise the elasticity. When the elasticity is low, the variety effect is large as an additional variety is highly valued. Thus, when the mass of exporters rises, it increases the market share of their composite products in the foreign country by more. This results in a large fluctuation of mass of

\footnotetext{
${ }^{32}$ Feenstra (1994) and Broda and Weinstein (2006) emphasize these gains to increased variety.
} 
exporters. Moreover, since with low $\theta$, the gains to additional domestic and imported establishments are relatively high, it is worthwhile to invest in creating more variety at home following a positive productivity shock. Hence the correlations of output and importers with domestic establishments are relatively high with low $\theta$, and the correlation of exporters becomes quite negative (Panel B of Figure 9).

Figure 10 shows how the model's properties vary with a wide range of the Armington elasticity, the elasticity of substitution between home and foreign aggregates, $1 /(1-\rho) \in[1,5]$. The volatility of the stock of establishments rises with the Armington elasticity but the increase is not large. With a low elasticity, the expenditure shares on home and foreign aggregates do not vary much over the business cycle. Thus, the value of new establishments are not sensitive to the aggregate shocks. With a high elasticity, however, the expenditure shares on imports vary more over the cycle resulting in greater fluctuations in the stock of establishments. The comovement of exporters, importers and entry with domestic establishments also varies with the elasticity of substitution (Panel B). As we make foreign and domestic goods more substitutable, the stock of domestic establishments become more strongly procyclical. The correlation of importers and exporters with the stock of domestic establishments are U-shaped and hump-shaped, respectively, in the Armington elasticity. These non-monotonic responses are due to two offsetting effects. First, increasing the Armington elasticity leads to greater reallocation from foreign to home goods following a positive productive shock. Second, the elasticity also affects the relative importance of the variety effect. As we have already seen, increasing the variety effect raises the comovement of importers and domestic establishments and lowers the comovement of exporters and domestic establishments. Thus, for relatively low values of the Armington elasticity the cost effect dominates while for relatively high values, the variety effect dominates.

\section{Exporter and Producer Lifecycle}

The model captures the qualitative features of entrants and exporters in terms of their size and persistence, but misses out quantitatively on some aspects of their size and growth. We now discuss how modifying the model to capture these elements does not noticeably affect the role of trade in increasing the procyclicality of the stock of producers.

On the export side, it is well known from Ruhl and Willis (2017), the sunk cost model of 
exporting captures the high persistence of exporting and relatively low exporter sales premium, but generates new exporters that are too large and survive too long in the export market. We explore the impact of missing out on this aspect of trade in two variations. ${ }^{33}$ First, we consider a variation with a higher sunk cost so that new exporters account for a smaller share of exports (denoted High Sunk). Second, we assume exporters in their first period of exporting face a temporarily high cost of shipping their goods, $\xi \geq 1$, which lowers their exports relative to domestic sales (denoted New Exporter Intensity)

With a higher sunk cost such that one-seventh as many exporters exit per period, we find a slightly lower procyclicality and volatility of establishments. With lower initial sales in the export market, we find slightly more procyclical and volatile establishments. We also find slightly more (less) procyclical exporters (importers) as trade flows become less procyclical.

We next describe a modification of the model that allows us to match the size discount of new producers and growth ${ }^{34}$ and show that matching these producer lifecycle moments does not substantially alter the cyclical behavior of entry. New producers now draw their productivity from a distribution with lower mean productivity $z_{E}<1$ and face an annual transition probability of $\rho_{E}$ to draw from the higher mean productivity level which is then an absorbing state. This leaves us with two types of firms, mature and immature producers. We choose $\left(z_{E}, \rho_{E}\right)$ so new producers start out 50 percent smaller and take 5 years to get to a stable size. The bottom panel of Figure $4 \mathrm{~B}$ plots establishment dynamics in this richer model.

The results for the closed and open economy versions of the model are reported in the columns Entrant's Disadvantage. Relative to the benchmark model with a simple life-cycle only from exporting, this firm-level growth process makes producers slightly more countercyclical in the closed economy (-0.16 vs. -0.01$)$ and less procyclical in the open economy (0.14 vs. 0.25$)$. The stock of establishments becomes more volatile (0.90 vs. 0.77$)$. Thus, trade has an even stronger effect on the dynamics of entry when we more closely model the lifecycle of producers. As new producers are persistently small, a boom in economic activity encourages more entry by new producers and foreign exporters. This effect is larger in the open economy than the closed economy. The model

\footnotetext{
${ }^{33}$ Alessandria, Choi and Ruhl (2014) build a rich heterogeneous producer model that matches the producer life-cycle and new exporter dynamics along both margins. They show that the stock of producers in that model behaves quite similarly following a trade liberalization to a sunk cost model with a much higher sunk cost.

${ }^{34}$ The model is described in more detail in the appendix.
} 
generates exporting that is too procyclical and importing that is not procyclical enough and thus the moments related to the cyclicality of traders should be viewed as only suggestive.

\section{Conclusion}

This paper studies the dynamics of entry, importing, and exporting over the business cycle. These three margins provide some useful evidence on the determinants of entry over the cycle and the propagation of shocks at home and abroad. Empirically, we document that the stock of domestic establishments and importers tend to move together over the business cycle, with importers more procyclical than producers. We find the stock of establishments and exporters tend to not move too closely together. We also find that fluctuations in the number of exporters and importers are considerably larger than those of domestic establishments over the cycle.

To study the source of these fluctuations in entry, importing, and exporting, we develop a two-country general equilibrium model with fixed and sunk costs of exporting and establishment creation that are subject to destination-specific aggregate productivity shocks. In this framework, exporters and establishments are durable assets but with different attributes than physical capital. Our model captures the salient features of establishment heterogeneity relating to the size of both exporters and entrants. With sunk and fixed costs of exporting and entry, the model generates fluctuations in entry, exporting, and importing similar to the data.

We find an important role of international trade for the dynamics in the stock of domestic establishments. Without international borrowing and lending, international trade is too smooth and entry by importers is much too procyclical. Without international trade, we find that the stock of establishments becomes acyclical and is much less volatile. Without fixed export costs, we find that the stock of establishments is highly procyclical and entry by importers is countercyclical. These results worsen if we ignore the dynamics of exporting from a sunk export cost. While these results are somewhat sensitive to the Armington elasticity and durability of investment in establishment creation, they do seem to hold for a range of parameters consistent with the data suggesting that findings on the source of the dynamics of firm entry in closed economy models may not be robust to the open economy.

Finally, our paper is a first attempt to study the interactions between producer entry along three important margins of importing, exporting, and producer creation. As such, we have focused 
on a fairly simple model of producer dynamics that captures the salient features of these key producers and their cyclical behavior but abstracts from the cyclical fluctuations in the characteristics of marginal entrants and exiters emphasized elsewhere. For instance, Lee and Mukoyama (2015) find marginal entrants are of better quality in recessions. It would be interesting to study how the characteristics of marginal entrants along all six margins vary over the cycle, but this would require more data and a richer model.

\section{References}

Alessandria, G., and H. Choi. (2007). "Do Sunk Costs of Exporting Matter for Net Export Dynamics?" Quarterly Journal of Economics, 122(1), 289-336.

. (2014a). "Establishment Heterogeneity, Exporter Dynamics, and the Effects of Trade Liberalization," Journal of International Economics, 94(2), 207-223.

. (2014b ). "Do Falling Iceberg Costs Explain Recent U.S. Export Growth?," Journal of International Economics, 94(2), 311-325.

Alessandria,G., H. Choi, and K. Ruhl. (2014). "Trade Adjustment Dynamics and the Welfare Gains from Trade," NBER Working Paper 20663, National Bureau of Economic Research.

Alessandria, G., J. Kaboski, and V. Midrigan. (2011). "U.S. Trade and Inventory Dynamics," American Economic Review, 101(3), 303-307.

. (2013). "Trade Wedges, Inventories, and International Business Cycles," Journal of Monetary Economics, 60(1), 1-20.

Alon, T., D. Berger, R. Dent, and B. Pugsley. (2017). "Older and Slower: The Startup Deficit's Lasting Effects on Aggregate Productivity Growth," Journal of Monetary Economics, 93(C), 86-88.

Aw, B., S. Chung, and M. Roberts. (1998). "Productivity and the Decision to Export: Micro Evidence from Taiwan and South Korea," NBER Working Paper 6558, National Bureau of Economic Research.

Backus, D., P. Kehoe, and F. Kydland. (1994). "Dynamics of the Trade Balance and the Terms of Trade: The J-Curve?" American Economic Review, 84(1), 84-103.

Baldwin, R. (1988). "Hysteresis in Import Prices: The Beachhead Effect," American Economic Review, 78(4), 773-785.

Baldwin, R., and R. Forslid. (2010). "Trade Liberalization with Heterogeneous Firms," Review of Development Economics, 14(2), 161-176.

Baldwin, R., and P. Krugman. (1989). "Persistent Trade Effects of Large Exchange Rate Shocks," Quarterly Journal of Economics, 104(4), 635-654.

Benassy, J. (1996). "Taste for Variety and Optimum Production Patterns in Monopolistic Competition," Economics Letters, 52(1), 41-47. 
Bernard, A. B., and J. B. Jensen. (1999). "Exceptional Exporter Performance: Cause, Effect, or Both?" Journal of International of Economics, 47(1), 1-25.

$561-569$. . (2004). "Why Some Firms Export," Review of Economics and Statistics, 86(2),

Bilbiie, F., F. Ghironi, and M. Melitz. (2012). "Endogenous Entry, Product Variety, and Business Cycles." Journal of Political Economy, 120(2), 304-45.

Broda, C., and D. Weinstein. (2006). "Globalization and the Gains from Variety," Quarterly Journal of Economics, 121(2), 541-585.

Campbell, J. R. (1998). "Entry, Exit Embodied Technology, and Business Cycles," Review of Economic Dynamics, 1(2), 371-408.

Chatterjee, S., and R. Cooper. (2014). "Entry and Exit, Product Variety and the Business Cycle." Economic Inquiry, 52(4), 1466-1484.

Clementi, G., and D. Palazzo. (2016). "Entry, Exit, Firm Dynamics, and Aggregate Fluctuations," American Economic Journal: Macroeconomics, 8(3), 1-41.

Clementi, G., A. Khan, B. Palazzo, and J. Thomas. (2015). "Entry, Exit and the Shape of Aggregate Fluctuations in a General Equilibrium Model with Capital Heterogeneity," mimeo

Clerides, S. K., S. Lach, and J. Tybout. (1998). "Is Learning by Exporting Important? Microdynamic Evidence from Colombia, Mexico, and Morocco," Quarterly Journal of Economics, 113(3), 903-947.

Cogley, T., and J. Nason. (1995). "Output Dynamics in Real Business Cycle Models," American Economic Review, 85(3), 492-511.

Comin, D., and M. Gertler. (2006). "Medium-Term Business Cycles," American Economic Review, 96(3), 523-551.

Cook, D. (2001). "Time to Enter and Business Cycles," Journal of Economic Dynamics and Control, 25(8), 1241-1261.

Cook, D. (2002). "Market Entry and International Propagation of Business Cycles," Journal of International Economics, 56(1), 155-175.

Das, S., M. Roberts, and J. Tybout. (2007). "Market Entry Costs, Producer Heterogeneity, and Export Dynamics," Econometrica, 75(3), 837-873.

Davis, S. J., J. C. Haltiwanger, and S. Schuh. (1996). Job creation and destruction, Cambridge, MA: MIT Press.

Devereux, M., A. Head, and B. Lapham. (1999). "Aggregate Fluctuations with Increasing Returns to Specialization and Scale," Journal of Economic Dynamics and Control, 20(4), 627-656.

Dixit, A. K. (1989). "Hysteresis, Import Penetration, and Exchange Rate Pass-Through," Quarterly Journal of Economics, 104(2), 205-228.

Fattal Jaef, R, and J. Ignacio Lopez. (2014). "Entry, trade costs, and international business cycles," Journal of International Economics, 94(2), 224-38. 
Feenstra, R. (1994). "New Product Varieties and the Measurement of International Prices", American Economic Review, 84(1), 157-75.

Ghironi, F. and M. Melitz. (2005). "International Trade and Macroeconomic Dynamics with Heterogenous Firms," Quarterly Journal of Economics, 120(3), 865-915.

Ghironi, F. and M. Melitz. (2007). "Trade Flow Dynamics with Heterogenous Firms," American Economic Review, 97(2), 356-361.

Gourio, F., T., Messer, and M. Siemer. (2016). "Firm Entry and Macroeconomic Dynamics: A State-Level Analysis," American Economic Review, 106(5), 214-218.

Head, A. (2002). "Aggregate Fluctuations with National and International Returns to Scale," International Economic Review, 43(4), 1101-1125.

Hopenhayn, H. (1992). "Entry, Exit, and Firm Dynamics in Long Run Equilibrium," Econometrica, 60(5), 1127-1150.

Kehoe, P., and F. Perri. (2002). "International Business Cycles with Endogenous Incomplete Markets," Econometrica, 70(3), 907-928.

Koellinger, P. and A. Thurik. (2012). "Entrepreneurship and the Business Cycle," The Review of Economics and Statistics, 94(4), 1143-1156.

Levchenko, A., L. Lewis, and L. Tesar. (2010). "The Collapse of International Trade During the 2008-2009 Crisis: In Search of the Smoking Gun," IMF Economic Review, 58(2), 214-53.

Lee,Y., and T. Mukoyama. (2008). "Entry Exit and Plant-level Dynamics over the Business Cycle," mimeo, University of Virginia.

. (2015). "Entry and Exit of Manufacturing Plants over the Business Cycle," European Economic Review, 77(C), 20-27,

Melitz, M. J. (2003). "The Impact of Trade on Intra-Industry Reallocations and Aggregate Industry Productivity," Econometrica, 71(6), 1695-1725.

Pugsley, B., and A. Sahin. (2015). "Grown-Up Business Cycles," Working Paper 15-33, Center for Economic Studies, Census Bureau.

Roberts, M., and J. Tybout. (1997). "The Decision to Export in Colombia: An Empirical Model of Entry with Sunk Costs," American Economic Review, 87(4), 545-564.

Ruhl, K. (2003). "Solving the Elasticity Puzzle," mimeo, University of Minnesota.

Ruhl, K., and J. Willis. (2017). "New Exporter Dynamics," International Economic Review, 58(3), 703-726.

Samaniego, R. M. (2008). "Entry, Exit and Business Cycles in a General Equilibrium Model," Review of Economic Dynamics, 11(3), 529-541.

Tian, C. (2018). "Firm-level Entry and Exit Dynamics over the Business Cycles," European Economic Review, 102(C), 298-326.

Veracierto, M. (2008). "Firing Costs And Business Cycle Fluctuations," International Economic Review, 49(1), 1-39. 
Woo, J. (2015). "The Cyclicality of Entry and Exit: A General Equilibrium Analysis with Imperfect Information," mimeo, University of Rochester. 


\section{Appendix}

\section{Data}

The extensive margin of trade is measured as the number of distinct varieties imported or exported by the U.S. A variety is a country-good pair (example SITC code 99999 imported/exported with Canada). For exports, variety is measured as an average of the number of 5-digit SITC code and 7 digit TSUSA except in 1978 where TSUSA code was used and in 1989 and 1990 the growth rate based on SITC was used an averaged across the two years (these were years were the classification systems were substantially altered). For imports, goods were classified at the 5-digit SITC code level. A measure of export participation is also constructed from Bernard and Jensen (1999) using the annual entry and exit rates of exporters from 1984 to 1992 and the Exporter Database from 1996 to 2015 (using firms with 1+ employees). The Exporter database is in NAICS from 97 to 2005 and in SIC from 96. The 97-98 report contains information by SIC and NAICS for 97 and 98. The 1996 data was scaled based on the relative size of SIC to NAICS in 97 . The stock of domestic establishments is measured as a count of the number of private manufacturing establishments and private establishments from the Census's Business Dynamics Statistics. GDP, exports, imports and investment are from the BEA from 1975 to 2016 and are measured in real terms. Employment is based on the BLS private employment series. Net exports are measured as the real trade balance divided by real GDP. The real exchange rate is the trade-weighted real exchange rate broad index from the BEA and the terms of trade is the ratio of export (BEA's nonagricultural export price) to import prices (BEA's non-petroleum import price). All series are logged (except net exports) and HP filtered using a smoothing parameter of 6.25 .

\section{Producer Lifecycle model}

Here we describe the producer lifecycle model. New producers draw their productivity from a $\log$ normal distribution with a lower mean, $\ln a\left(i, s^{t}\right) i i d N\left(\ln z_{E}, \alpha_{a}^{2}\right)$. These immature produces cannot export. Each period, they face a transition probability of $\rho_{E}$ to draw their productivity from the higher mean productivity level, $\ln a\left(i, s^{t}\right) i i d N\left(0, \alpha_{a}^{2}\right)$ which is then an absorbing state. The value of a producer with $a$ drawn from the distribution with a lower mean $z_{E}$ is given by

$$
\begin{aligned}
V^{L}\left(a, k, m, s^{t}\right)= & \max \left\{\Pi_{h}\left(a, k, m ; s^{t}\right)+n_{d} \int_{s^{t+1}} Q\left(s^{t+1} \mid s^{t}\right) k^{\prime} d s^{t+1}\right. \\
& +\left(1-n_{d}\right) \int_{s^{t+1}}\left[\left(1-\rho_{E}\right) \int_{a^{\prime}} Q\left(s^{t+1} \mid s^{t}\right) \phi\left(a^{\prime} \mid z_{E}\right) V^{L}\left(a^{\prime}, k^{\prime}, 0 ; s^{t+1}\right) d a^{\prime}\right. \\
& \left.\left.+\rho_{E} \int_{a^{\prime}} Q\left(s^{t+1} \mid s^{t}\right) \phi\left(a^{\prime}\right) V\left(a^{\prime}, k^{\prime}, m^{\prime} ; s^{t+1}\right) d a^{\prime}\right] d s^{t+1}\right\},
\end{aligned}
$$

where $\phi\left(a^{\prime} \mid z_{E}\right)$ and $\phi\left(a^{\prime}\right)$ are the probability of an idiosyncractic shock $\ln a^{\prime}$ with its mean $\ln z_{E}$ and 0 , respectively. The entry condition is given as

$$
\begin{aligned}
V^{E}\left(s^{t}\right)= & \max _{k_{E}}\left\{-f_{E}\left(s^{t}\right)-P\left(s^{t}\right) k_{E}\left(s^{t}\right)+n_{d} \int_{s^{t+1}} Q\left(s^{t+1} \mid s^{t}\right) k_{E}\left(s^{t}\right) d s^{t+1}\right. \\
& \left.+\left(1-n_{d}\right) \int_{s^{t+1}} \int_{a^{\prime}} Q\left(s^{t+1} \mid s^{t}\right) \phi\left(a^{\prime} \mid z_{E}\right) V^{L}\left(a^{\prime}, k_{E}, 0, s^{t+1}\right) d a^{\prime} d s^{t+1}\right\} \geq 0,
\end{aligned}
$$

where $k_{E}$ is the capital stock chosen by new establishments. As an entrant starts the next period with a productivity drawn from the distribution with mean of $z_{E}$ it will choose a capital stock different from that of incumbent which draws the productivity from the mean of $z_{E}$. 
Table 1: Summary Statistics (HP deviations, 1977 to 2015)

\begin{tabular}{|c|c|c|c|c|c|c|c|}
\hline & & \multicolumn{6}{|c|}{ Volatility relative to GDP } \\
\hline & $\mathrm{Y}$ & Exports & Imports & Mfr estabs & Estabs & Exporters & Importers \\
\hline & $1.23^{*}$ & 2.71 & 2.87 & 0.45 & 0.50 & 1.48 & 1.30 \\
\hline \multicolumn{8}{|l|}{ Correlation } \\
\hline Y & 1.00 & 0.58 & 0.88 & 0.41 & 0.47 & -0.08 & 0.61 \\
\hline Exports & 0.58 & 1.00 & 0.43 & 0.43 & 0.31 & 0.37 & 0.14 \\
\hline Imports & 0.88 & 0.43 & 1.00 & 0.28 & 0.44 & -0.17 & 0.70 \\
\hline Mfr estabs & 0.41 & 0.43 & 0.28 & 1.00 & 0.81 & -0.01 & 0.26 \\
\hline Estabs & 0.47 & 0.31 & 0.44 & 0.81 & 1.00 & -0.28 & 0.31 \\
\hline Exporters & -0.08 & 0.37 & -0.17 & -0.01 & -0.28 & 1.00 & -0.25 \\
\hline Importers & 0.61 & 0.14 & 0.70 & 0.26 & 0.31 & -0.25 & 1.00 \\
\hline GDP & $\mathrm{Y}$ & Exports & Imports & Mfr estabs & Estabs & Exporters & Importers \\
\hline $\mathrm{t}-1$ & 0.3 & 0.44 & 0.08 & 0.79 & 0.57 & -0.05 & 0.12 \\
\hline $\mathrm{t}$ & 1 & 0.58 & 0.88 & 0.41 & 0.47 & -0.08 & 0.61 \\
\hline $\mathrm{t}+1$ & 0.3 & -0.1 & 0.43 & -0.09 & 0.23 & -0.27 & 0.26 \\
\hline Estabs & $\mathrm{Y}$ & Exports & Imports & Mfr estabs & Estabs & Exporters & Importers \\
\hline $\mathrm{t}-1$ & 0.23 & 0.32 & -0.04 & 0.4 & 0.39 & -0.12 & -0.05 \\
\hline $\mathrm{t}$ & 0.47 & 0.31 & 0.44 & 0.81 & 1 & -0.28 & 0.31 \\
\hline$t+1$ & 0.57 & 0.03 & 0.66 & 0.28 & 0.39 & -0.09 & 0.57 \\
\hline Mfr estabs & $\mathrm{Y}$ & Exports & Imports & Mfr estabs & Estabs & Exporters & Importers \\
\hline $\mathrm{t}-1$ & -0.09 & 0.12 & -0.32 & 0.38 & 0.28 & 0.05 & -0.23 \\
\hline $\mathrm{t}$ & 0.41 & 0.43 & 0.28 & 1 & 0.81 & -0.01 & 0.26 \\
\hline $\mathrm{t}+1$ & 0.79 & 0.43 & 0.76 & 0.38 & 0.4 & 0.14 & 0.54 \\
\hline
\end{tabular}

*Absolute Volatility 
Table 2: Parameter Values

\begin{tabular}{|c|c|}
\hline Preferences & $\beta=0.960, \sigma=2, \gamma=0.383$ \\
\hline Production & $\begin{array}{l}\lambda=0.566, \rho=0.750, \theta=5 / 6 \\
\alpha=0.360, \delta=0.100, \sigma_{a}=0.450, n_{d}=0.054 \\
M_{11}=M_{22}=0.815, M_{12}=M_{21}=0 \\
\operatorname{Var}\left(\sigma_{\varepsilon}\right)=\operatorname{Var}\left(\sigma_{\varepsilon^{*}}\right)=0.013^{2}, \operatorname{Corr}\left(\varepsilon, \varepsilon^{*}\right)=0.250 \\
\overline{f_{E}}=0.751, \overline{f_{0}}=0.116, \overline{f_{1}}=0.036\end{array}$ \\
\hline Benchmark & Alternative Models \\
\hline Closed & $\overline{f_{E}}=0.876$ \\
\hline No fixed export costs & $\overline{f_{E}}=0.876, \bar{f}_{0}=\overline{f_{1}}=0$ \\
\hline No Sunk & $\overline{f_{E}}=0.751, \overline{f_{0}}=0.045, \overline{f_{1}}=0.045, \sigma_{a}=0.295$ \\
\hline Overhead Costs & $\overline{f_{E}}=0.36, \overline{f_{C}} / \overline{f_{E}}=0.1, \overline{f_{0}}=0.110, \overline{f_{1}}=0.035$ \\
\hline High Sunk Cost & $\overline{f_{E}}=0.758, \overline{f_{0}}=0.242, \overline{f_{1}}=0.034, \sigma_{a}=0.68$ \\
\hline Starter export intensity & $\overline{f_{E}}=0.741, \overline{f_{0}}=0.075, \overline{f_{1}}=0.052, \sigma_{a}=0.412, \xi=1.224$ \\
\hline \multicolumn{2}{|l|}{ Entrants' Disadvantage } \\
\hline Sunk & $z_{E}=0.886, \rho_{E}=0.200, \sigma_{a}=0.370, \overline{f_{E}}=0.687, \overline{f_{0}}=0.103, \overline{f_{1}}=0.040$ \\
\hline Closed & $z_{E}=0.852, \rho_{E}=0.200, \overline{f_{E}}=0.798$ \\
\hline
\end{tabular}


Table 3: Key Moments on Entry and Exporting over the Cycle

\begin{tabular}{|c|c|c|c|c|c|c|c|c|c|}
\hline & \multirow[b]{2}{*}{ Data } & \multirow[b]{2}{*}{ Benchmark } & \multirow[b]{2}{*}{ Closed } & \multirow[b]{2}{*}{$\begin{array}{c}\text { Financial } \\
\text { autarky }\end{array}$} & \multirow{2}{*}{$\begin{array}{c}\text { No fixed } \\
\text { export } \\
\text { costs }\end{array}$} & \multirow{2}{*}{$\begin{array}{c}\text { No sunk } \\
\text { export } \\
\text { costs }\end{array}$} & \multicolumn{3}{|c|}{ No shocks to } \\
\hline & & & & & & & $\begin{array}{l}\text { export } \\
\text { costs }\end{array}$ & $\begin{array}{c}\text { all } \\
\text { costs }\end{array}$ & $\begin{array}{c}\text { Entry } \\
\text { costs }\end{array}$ \\
\hline \multicolumn{10}{|c|}{ Volatility relative to output } \\
\hline Imports, Exports & 2.79 & 2.00 & - & 0.91 & 1.27 & 2.28 & 1.08 & 1.77 & 2.00 \\
\hline All est. & 0.50 & 0.77 & 0.55 & 0.43 & 0.61 & 0.72 & 0.55 & 0.10 & 0.12 \\
\hline Exporters, Importers & 1.48 & 1.46 & - & 0.52 & 0.61 & 1.86 & 0.69 & 0.96 & 1.42 \\
\hline \multicolumn{10}{|l|}{ Correlation } \\
\hline (Y, Exports) & 0.58 & 0.32 & - & 0.82 & 0.35 & 0.35 & 0.13 & 0.25 & 0.33 \\
\hline (Y, Imports) & 0.88 & 0.66 & - & 0.76 & 0.61 & 0.66 & 0.47 & 0.62 & 0.72 \\
\hline (Y, All est.) & 0.47 & 0.25 & -0.01 & 0.02 & 0.92 & 0.24 & 0.23 & 0.23 & 0.24 \\
\hline (Y, Exporters) & -0.08 & 0.13 & - & 0.55 & 0.92 & 0.27 & -0.37 & 0.25 & 0.32 \\
\hline (Y, Importers) & 0.61 & 0.59 & - & 0.92 & 0.02 & 0.65 & -0.41 & 0.32 & 0.70 \\
\hline (All est., Exporters) & -0.28 & 0.00 & - & 0.01 & 1.00 & 0.11 & -0.02 & -0.16 & -0.25 \\
\hline (All est., Importers) & 0.31 & 0.07 & - & 0.16 & -0.08 & -0.31 & -0.21 & -0.02 & -0.14 \\
\hline (Exports, Exporters) & 0.37 & 0.95 & - & 0.86 & 0.33 & 0.99 & 0.51 & 0.91 & 0.95 \\
\hline \multirow[t]{2}{*}{ (Imports, Importers) } & 0.70 & 0.95 & - & 0.86 & 0.33 & 0.99 & 0.51 & 0.91 & 0.95 \\
\hline & $\begin{array}{c}\text { Export } \\
\text { costs in } \\
\text { home labor }\end{array}$ & $\begin{array}{l}\text { Overhead } \\
\text { costs }\end{array}$ & $\begin{array}{c}\text { Trade } \\
\text { cost } \\
\text { shocks }\end{array}$ & $\begin{array}{l}\text { High } \\
\text { sunk }\end{array}$ & $\begin{array}{c}\text { New } \\
\text { exporter }\end{array}$ & $\begin{array}{l}\text { Entra } \\
\text { disadva } \\
\text { open }\end{array}$ & $\begin{array}{l}\text { nts' } \\
\text { ntage } \\
\text { closed }\end{array}$ & & \\
\hline \multicolumn{10}{|c|}{ Volatility relative to output } \\
\hline Imports, Exports & 2.12 & 2.07 & 2.83 & 1.74 & 2.31 & 1.84 & - & & \\
\hline All est. & 0.81 & 0.77 & 0.70 & 0.76 & 0.81 & 0.90 & 0.59 & & \\
\hline Exporters, Importers & 1.61 & 1.53 & 2.00 & 1.03 & 1.75 & 1.28 & - & & \\
\hline \multicolumn{10}{|l|}{ Correlation } \\
\hline (Y, Exports) & 0.29 & 0.23 & 0.55 & 0.31 & 0.27 & 0.31 & - & & \\
\hline (Y, Imports) & 0.62 & 0.60 & 0.83 & 0.67 & 0.57 & 0.70 & - & & \\
\hline (Y, All est.) & 0.29 & 0.41 & 0.22 & 0.23 & 0.28 & 0.14 & -0.16 & & \\
\hline (Y, Exporters) & 0.11 & 0.10 & 0.36 & 0.18 & 0.23 & 0.25 & - & & \\
\hline (Y, Importers) & 0.52 & 0.53 & 0.81 & 0.37 & 0.51 & 0.64 & - & & \\
\hline (All est., Exporters) & 0.01 & -0.11 & 0.02 & 0.18 & -0.01 & 0.14 & - & & \\
\hline (All est., Importers) & 0.05 & 0.25 & 0.21 & -0.13 & 0.00 & -0.11 & - & & \\
\hline (Exports, Exporters) & 0.96 & 0.96 & 0.93 & 0.90 & 0.97 & 0.96 & - & & \\
\hline (Imports, Importers) & 0.96 & 0.96 & 0.93 & 0.90 & 0.97 & 0.96 & - & & \\
\hline
\end{tabular}


Figure 1: Long-run Changes in Producers, Exporters, Importers A. US Economy

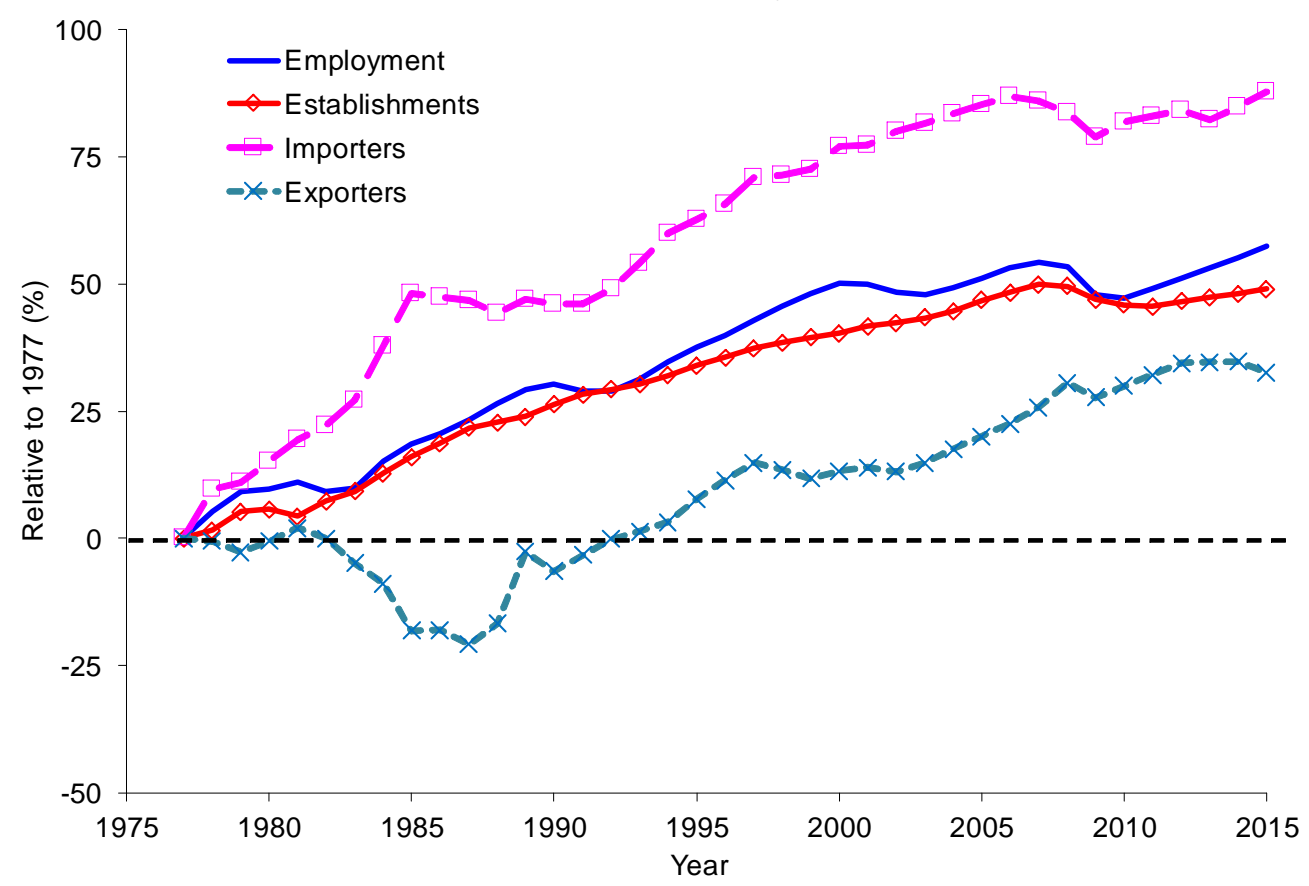

B. Manufacturing

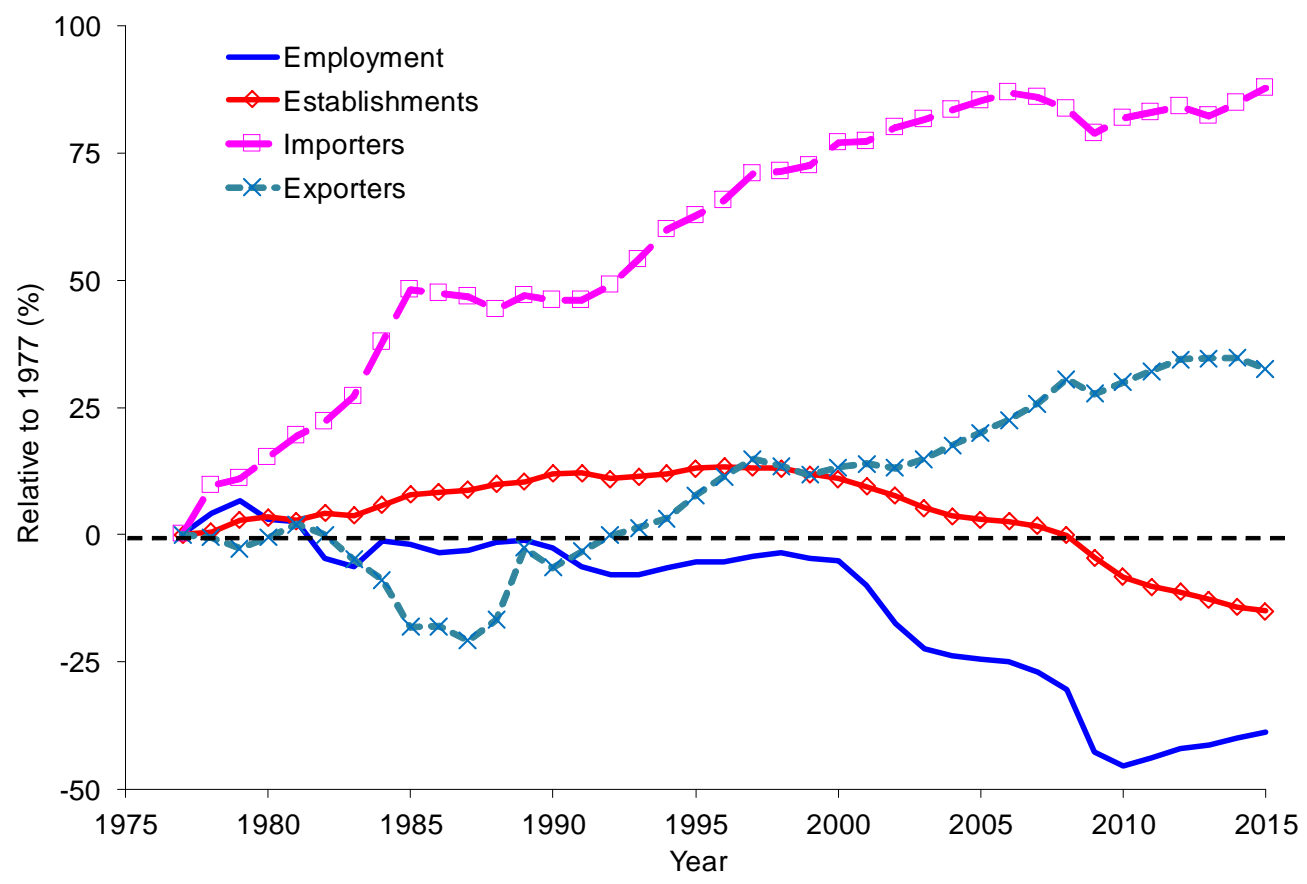


Figure 2: Cyclical Fluctuations in Establishments, Exporters, and Importers

A. US Economy

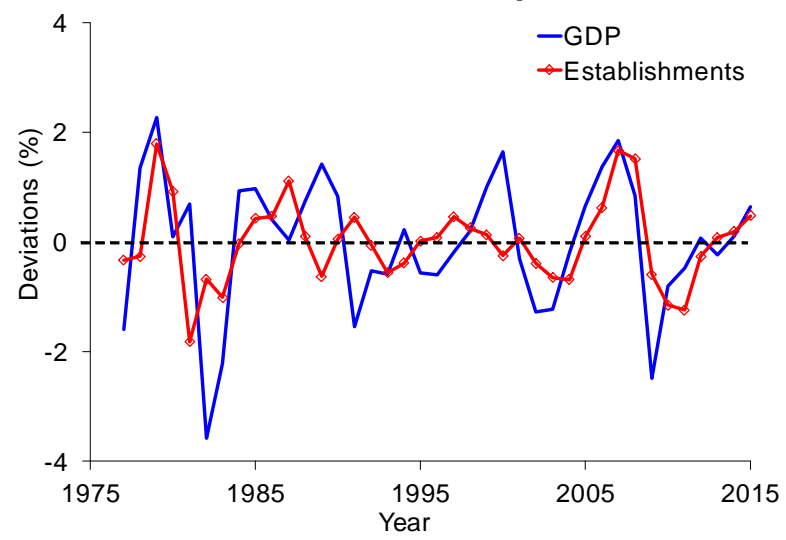

C. Imports and Importers

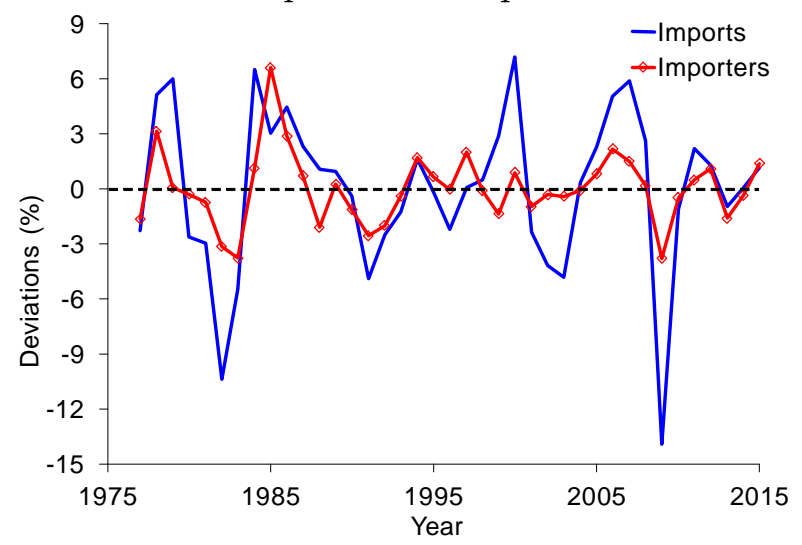

B. Exports and Exporters

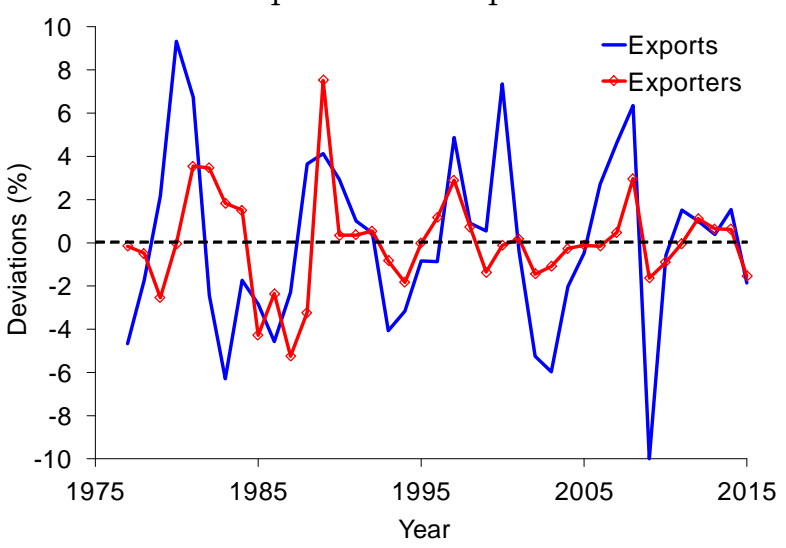

D. Net Trade and Exporters

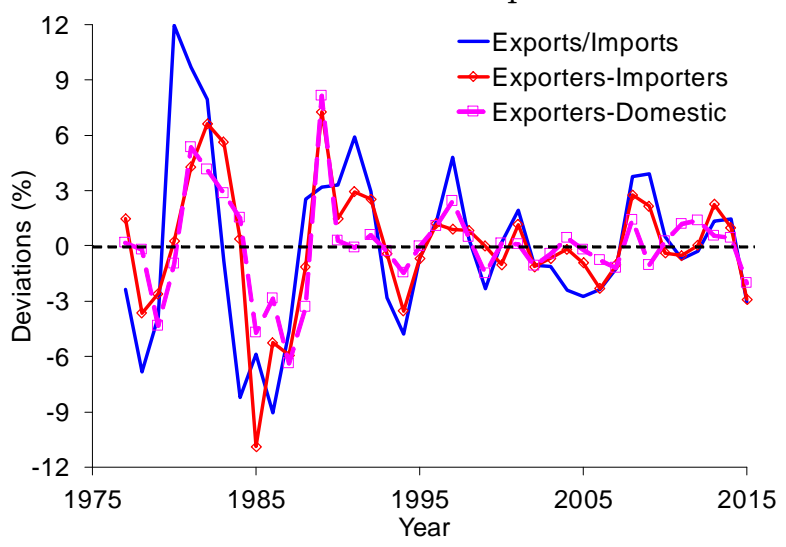


Figure 3: Time Line

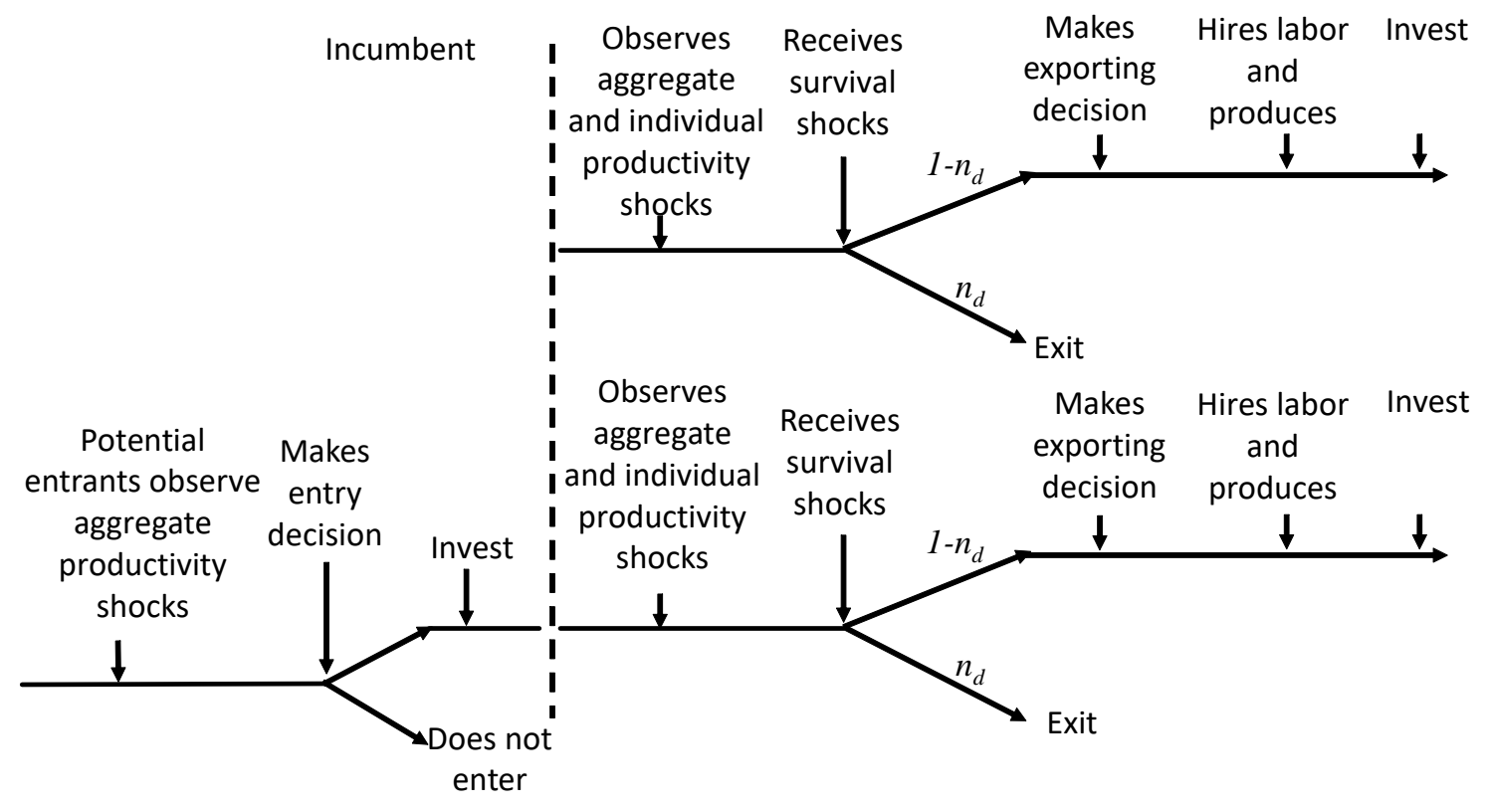


Figure 4: Employment Dynamics of Establishments

A. Benchmark

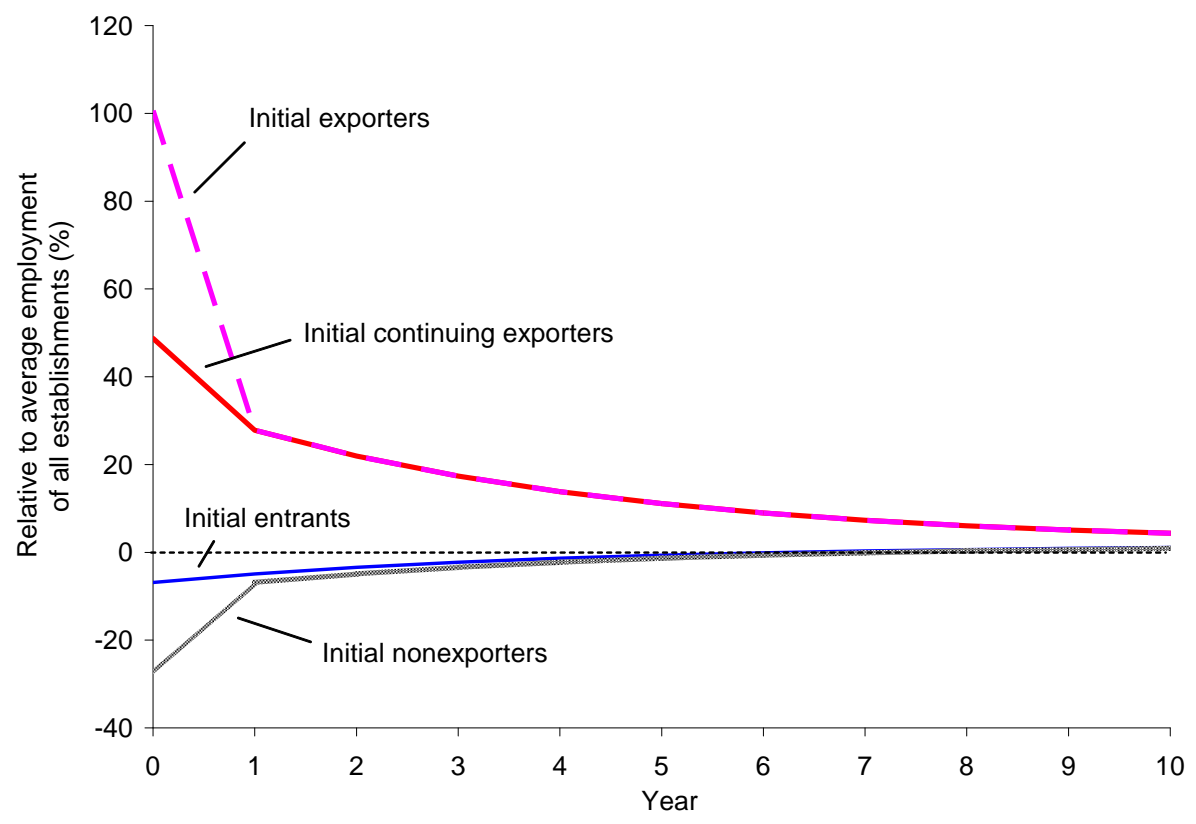

B. Entrants' Disadvantage

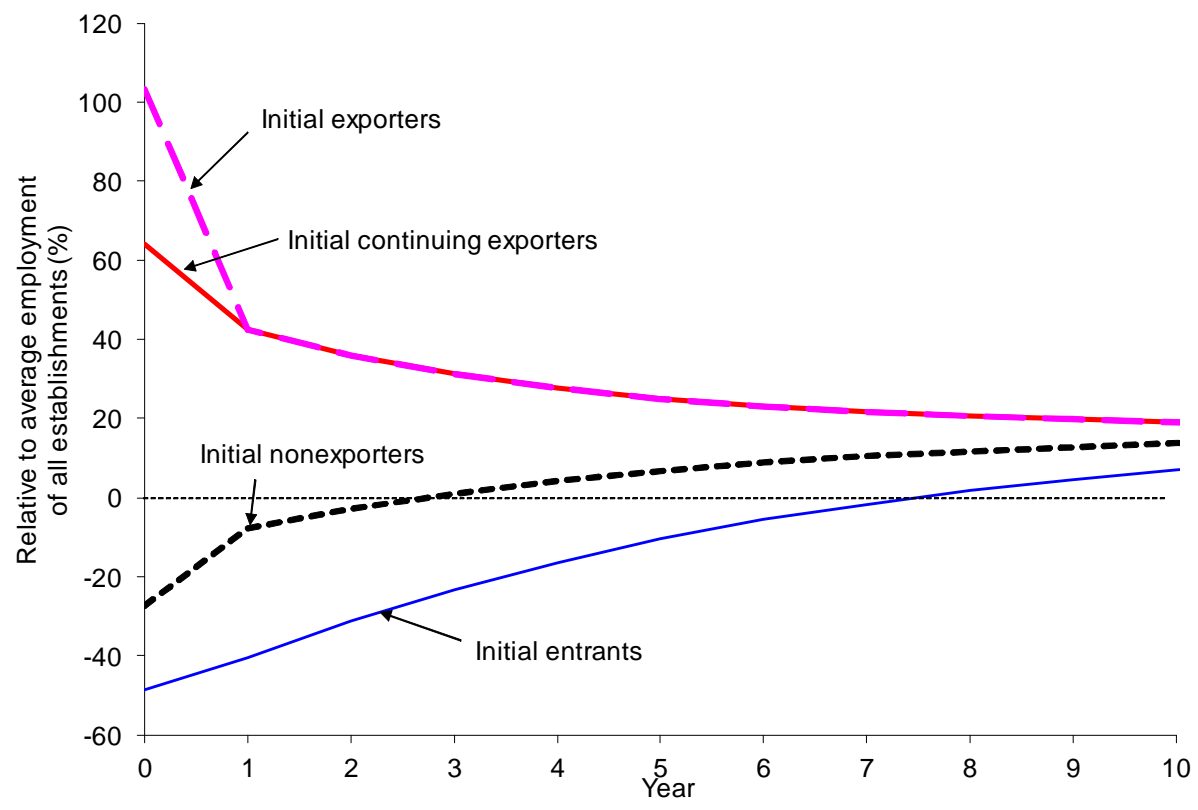


Figure 5: Participation Margins response to 1 sd Home Productivity Shock

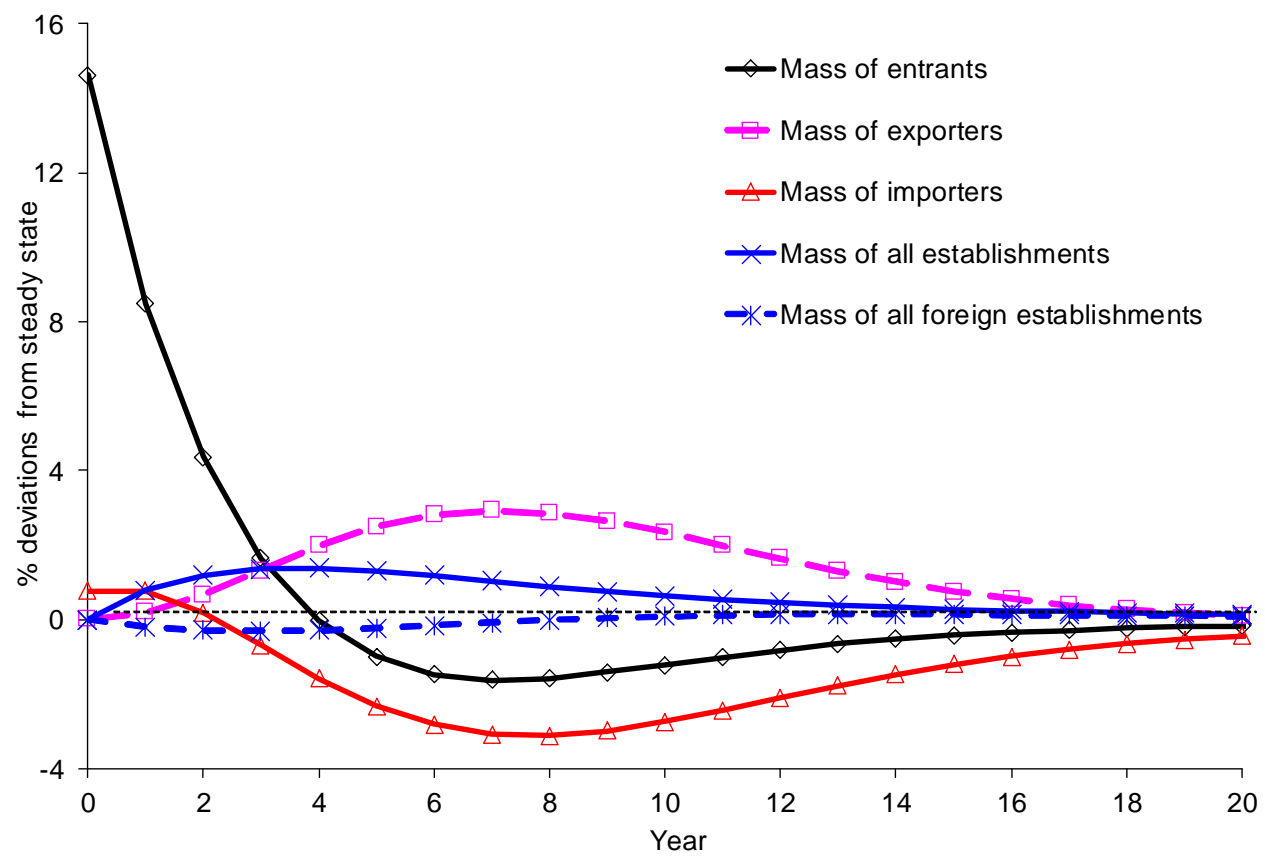

Figure 6: Home Aggregate response to 1 sd Home Productivity Shock

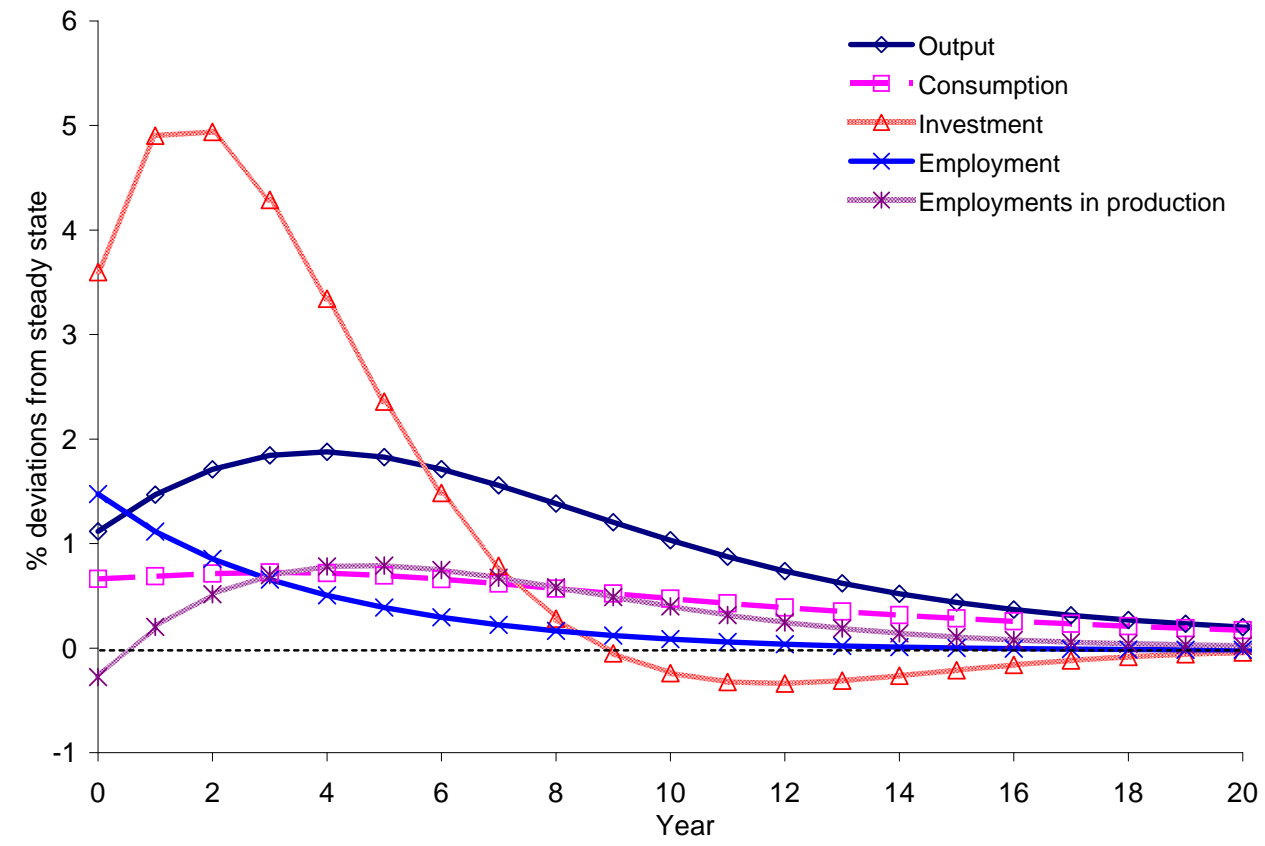


Figure 7: Home Output Response to 1 sd Home Productivity Shock in Model Variants A. No Entrant's Disadvantage

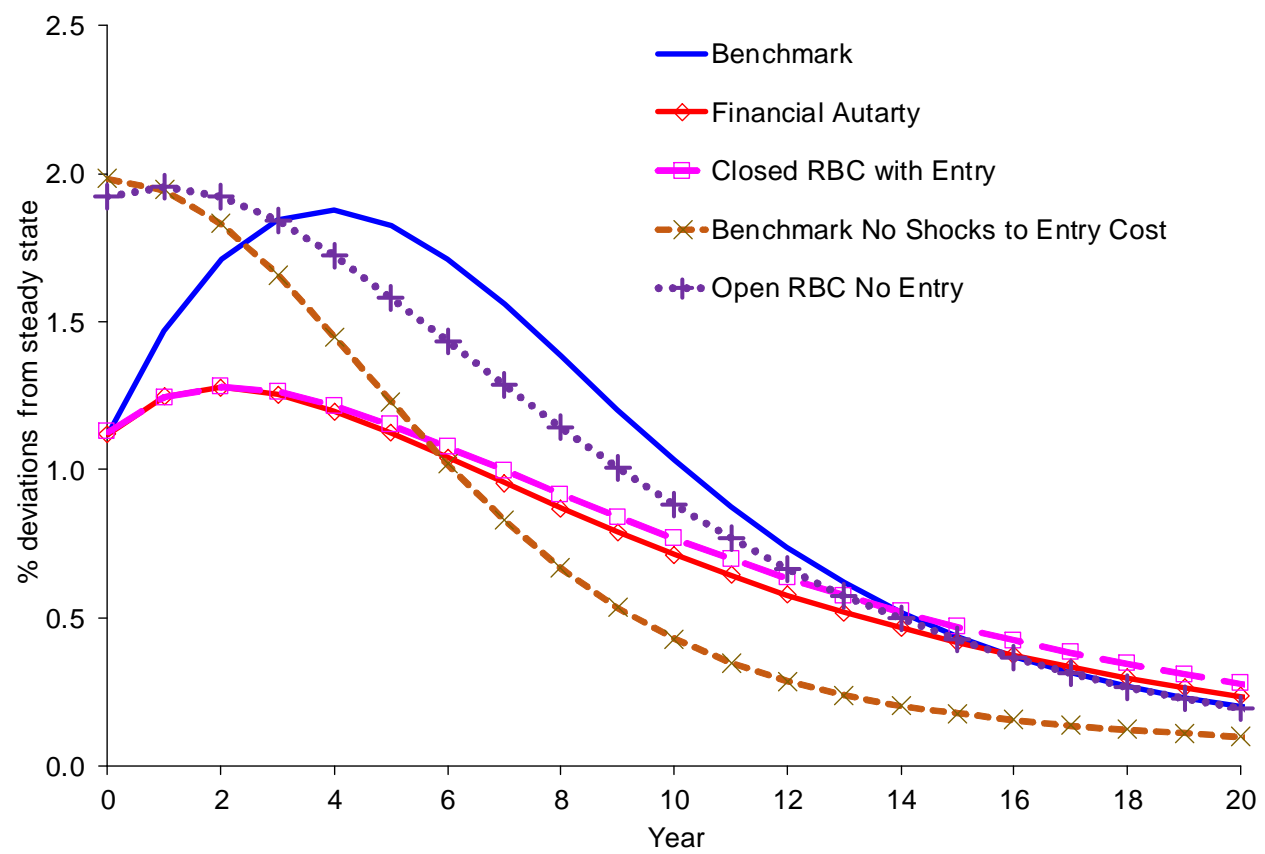

B. Entrant's Disadvantage

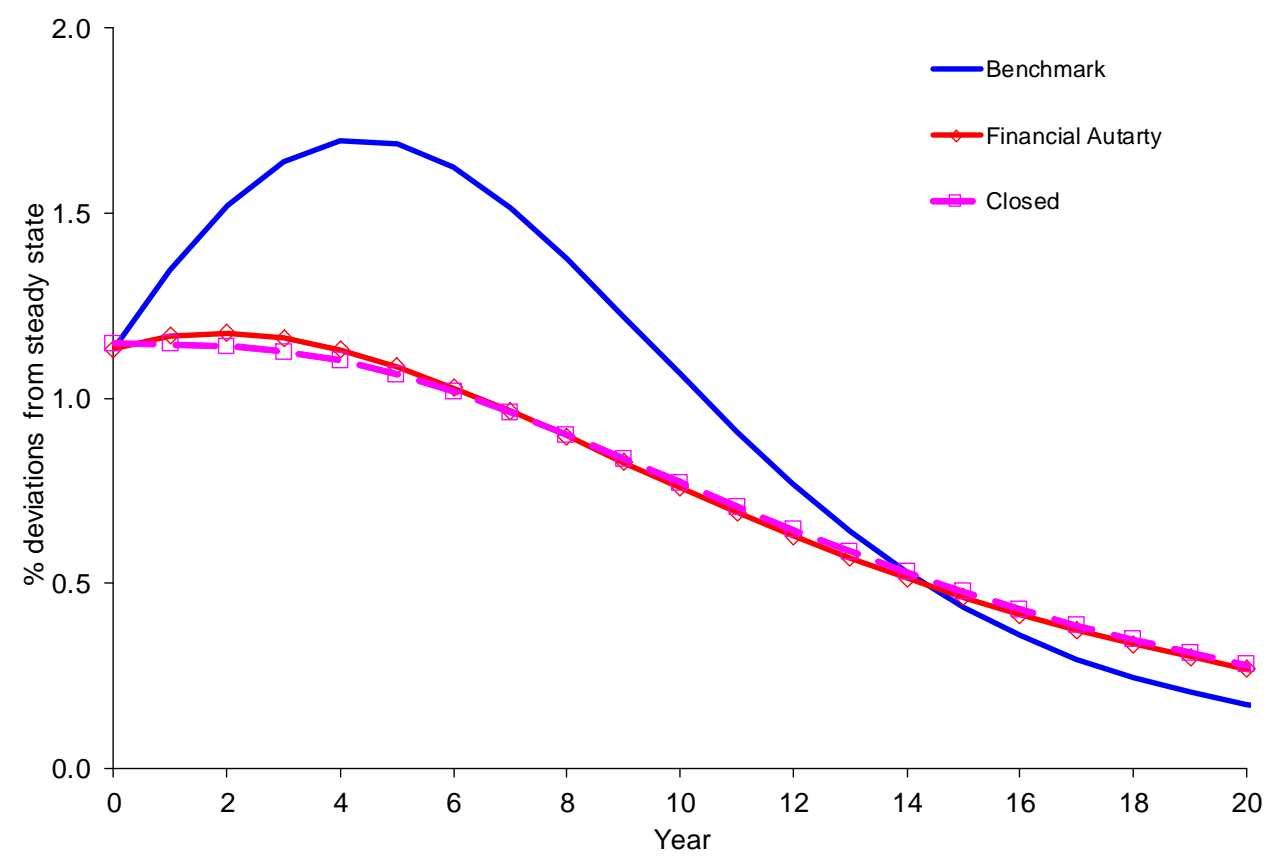


Figure 8: Sensitivity Analysis: Exit Rate

A. Labor Shares for Sunk and Fixed Costs

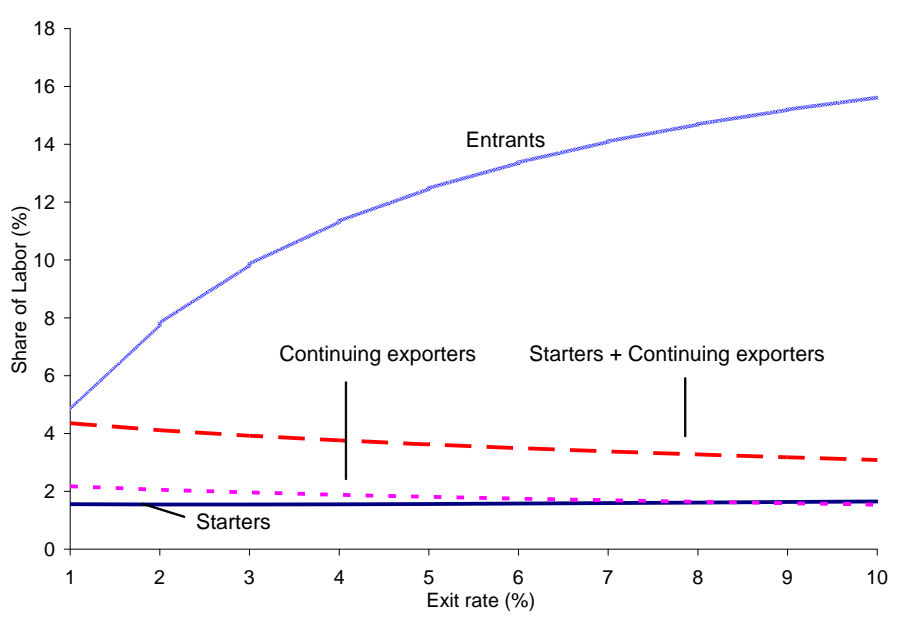

B. Volatility of Masses of Exporters and All Establishments

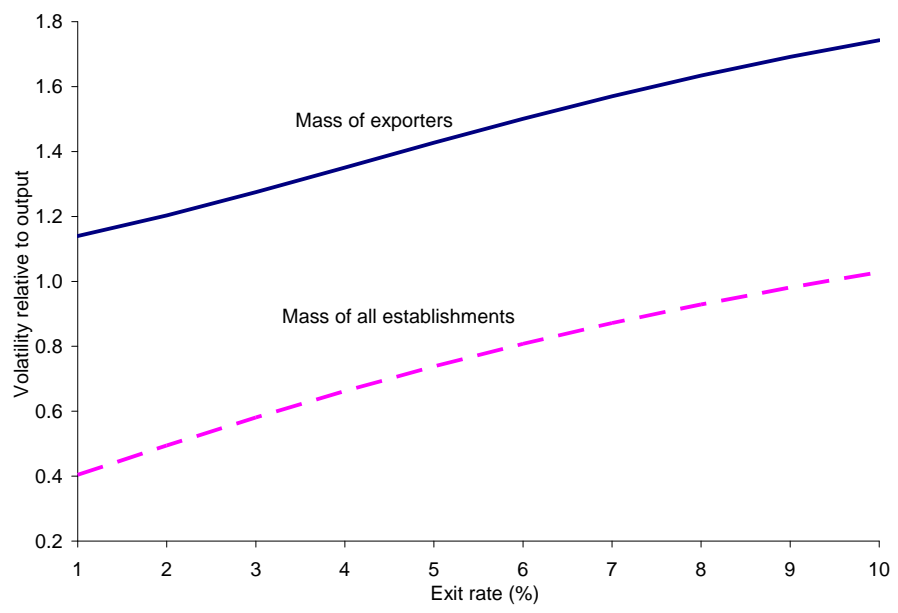

C. Correlation with Mass of All Establishments

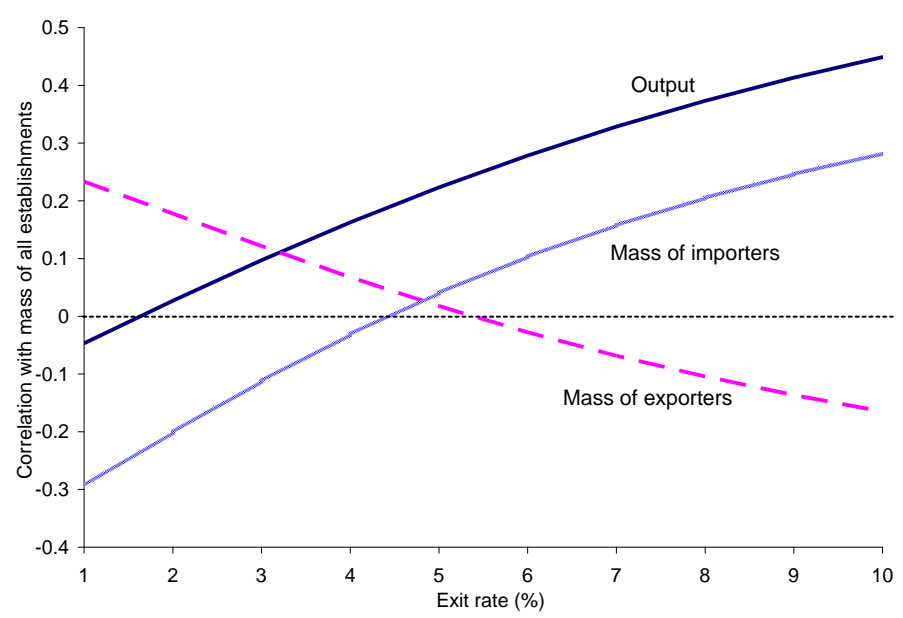


Figure 9: Sensitivity Analysis: Elasticity of Substitution Between Varieties within a Country

A. Volatility of Masses of Exporters and All Establishments

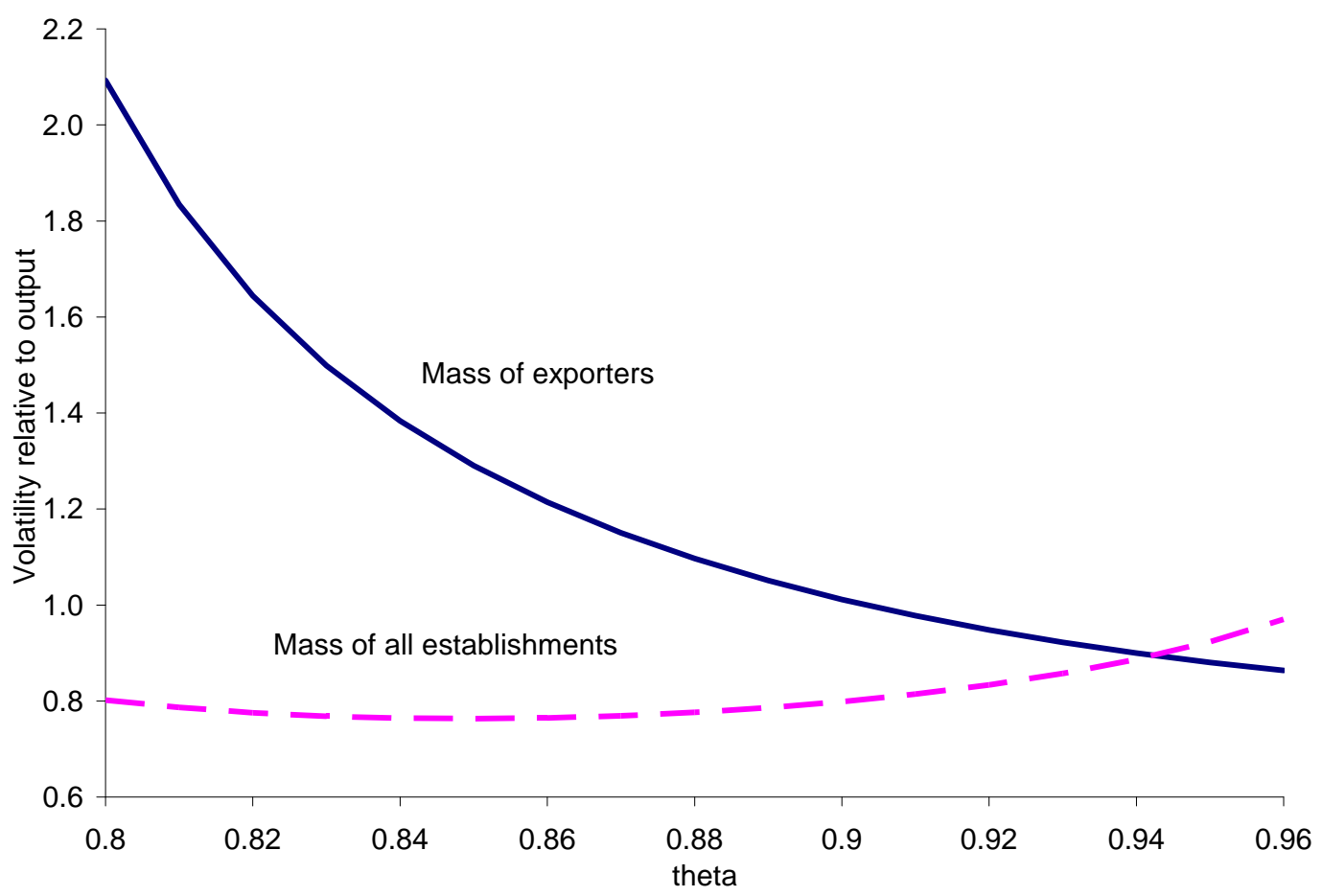

B. Correlation with Mass of All Establishments

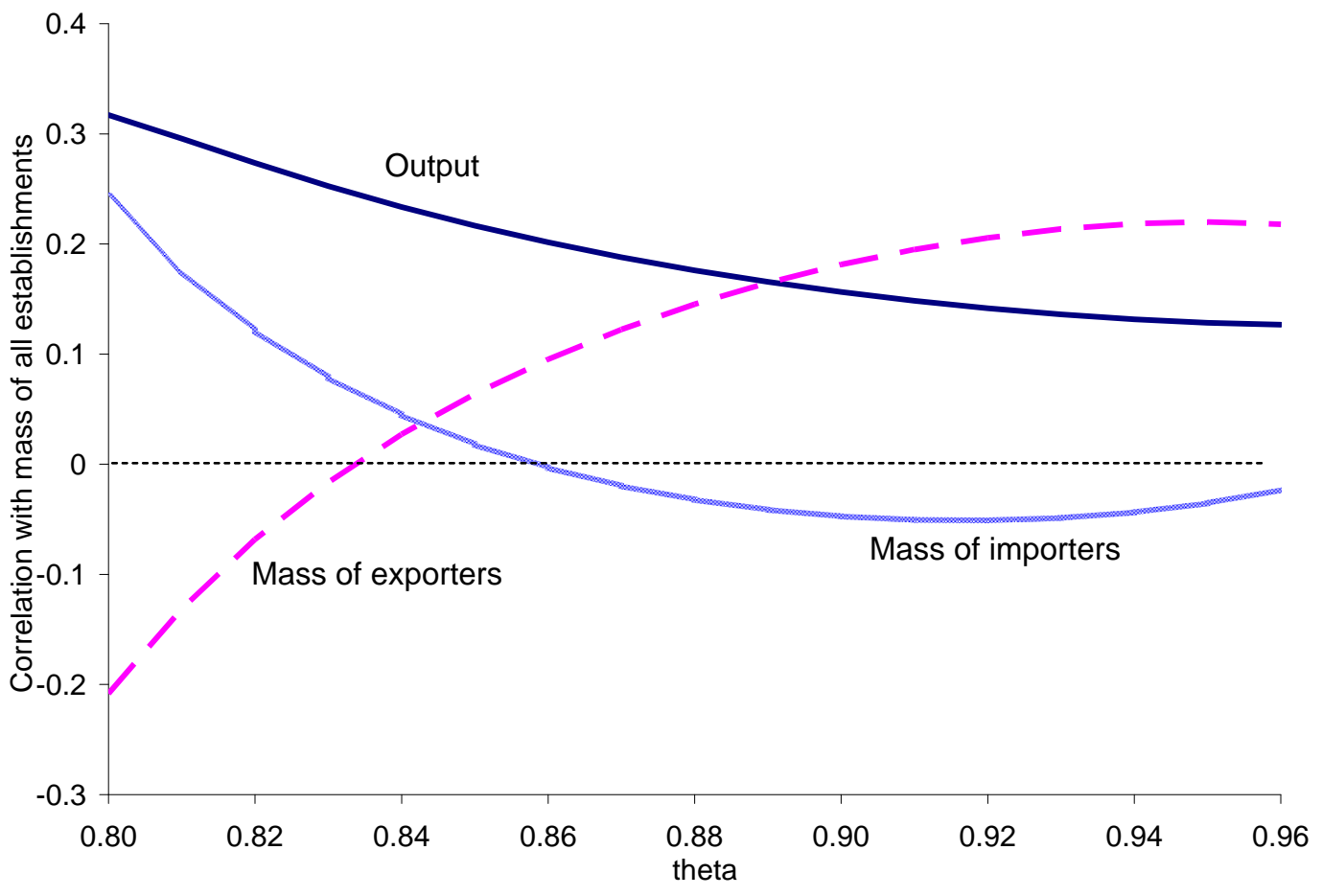


Figure 10: Sensitivity Analysis: Elasticity of Substitution Between Home and Foreign Composites A. Volatility of Masses of Exporters and All Establishments

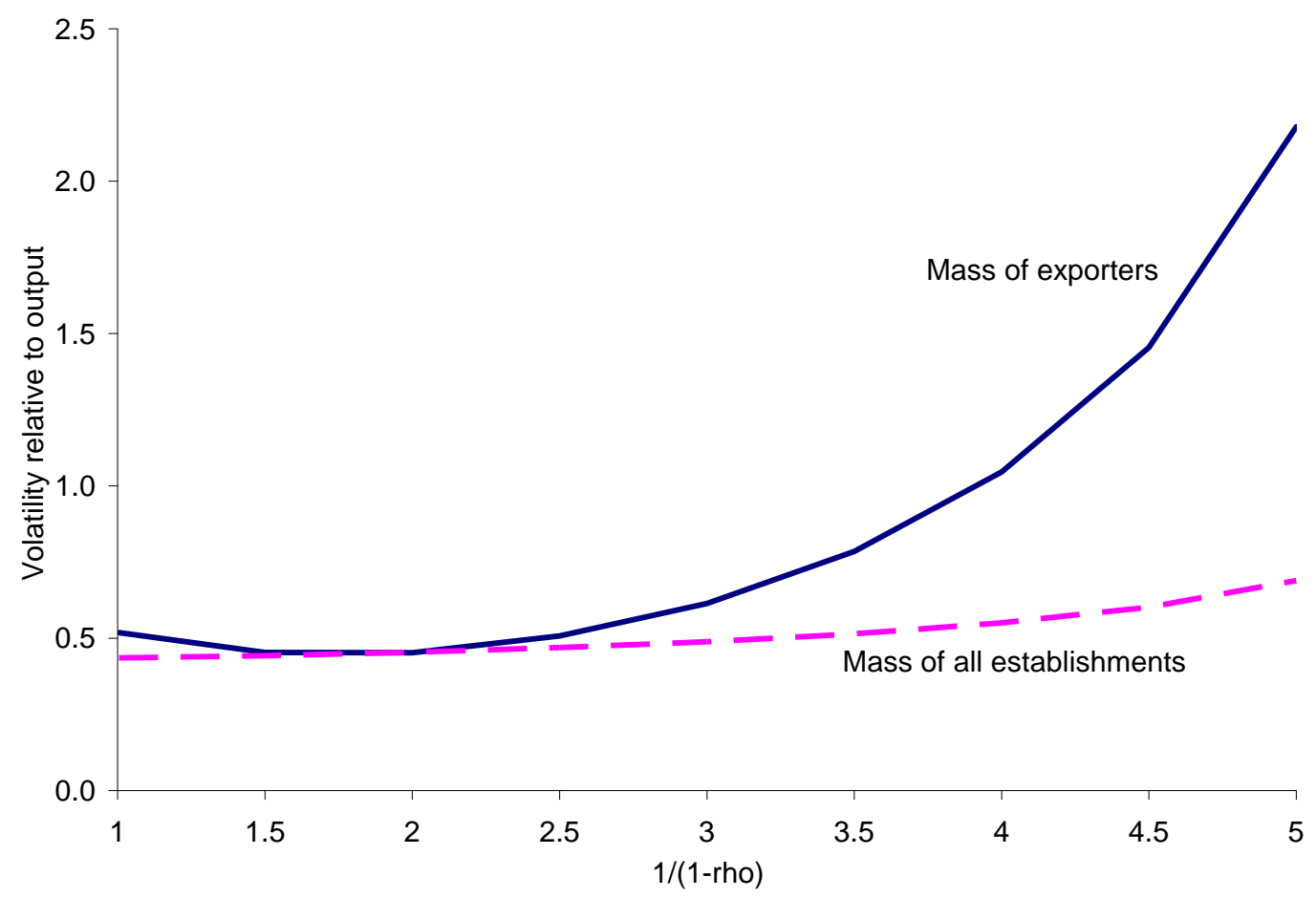

B. Correlation with Mass of All Establishments

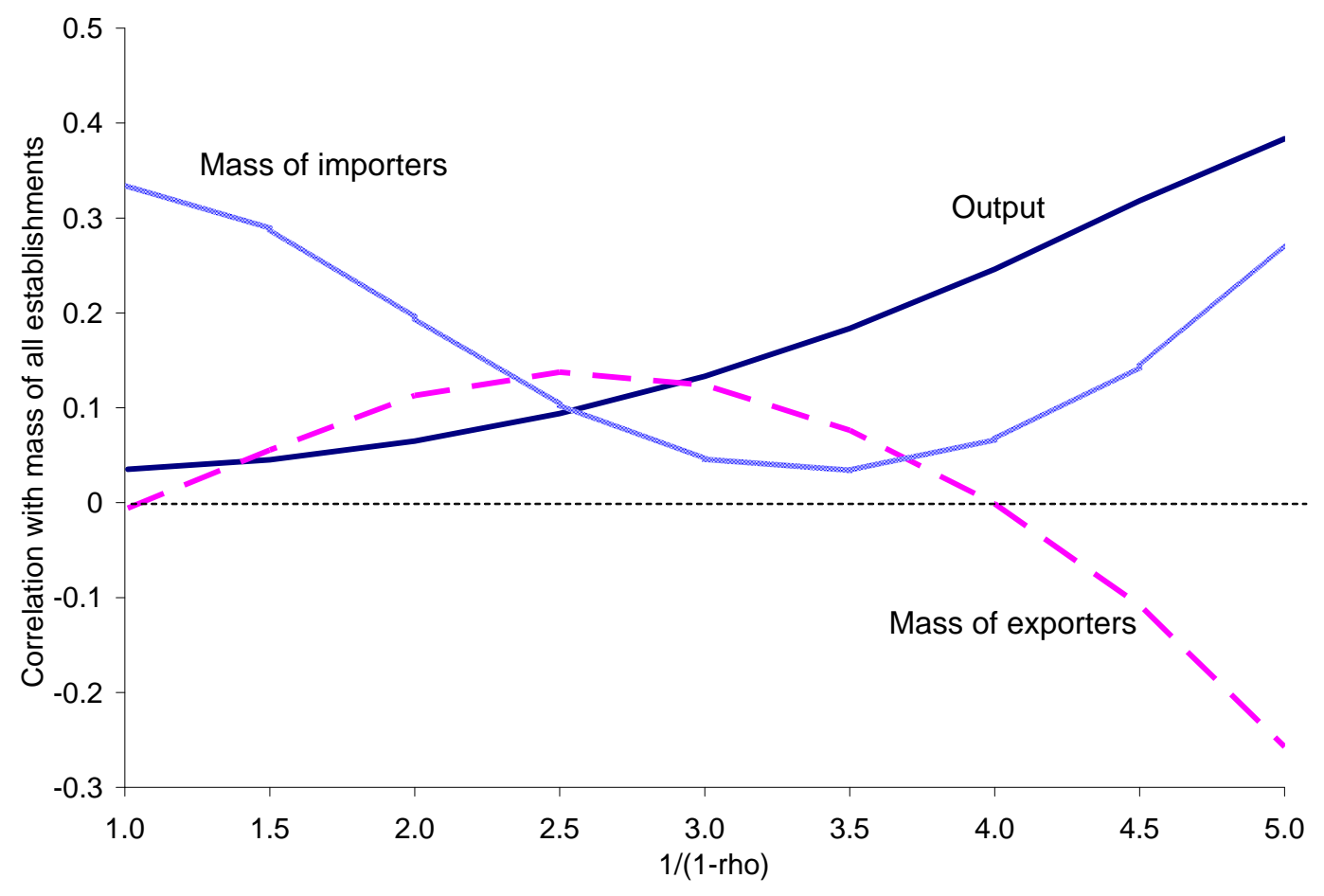

